\title{
CAMA
}

Centre for Applied Macroeconomic Analysis

\section{The Industrial Impact of Economic Uncertainty Shocks in Australia}

\section{CAMA Working Paper 89/2019 December 2019}

\section{Hamish Burrell}

Tasmanian School of Business and Economics, University of Tasmania

\section{Joaquin Vespignani}

Tasmanian School of Business and Economics, University of Tasmania Centre for Applied Macroeconomic Analysis, ANU

\section{Abstract}

This study establishes the first empirical evidence of the impact of economic uncertainty shocks on industry-level investment, output and employment in Australia. We find the Construction and Financial and Insurance Services industries are the most impacted by a shock to economic uncertainty. Statistically significant declines are observed for investment, output and employment in the Construction industry, and in terms of magnitude, the declines in output and employment are the largest across all industries studied. Likewise, the Financial and Insurance Services industry experiences declines across investment, output and employment, and undergoes the largest decline in investment in comparison to all other industries examined. Economic uncertainty explains the most substantial portion of the variation in Financial and Insurance Services investment and output, highlighting the detrimental effect it has on the Financial and Insurance Services industry. Furthermore, Health Care and Social Assistance output and Professional, Scientific and Technical Services investment experience considerable declines, and in contrast, Public Administration and Safety is shown to be the least impacted industry. 


\section{Keywords}

Economic Uncertainty, Economic Uncertainty Shocks, SVAR, Australian economy, Australian Industries

\section{JEL Classification}

C10, C32, E00, E30

\section{Address for correspondence:}

(E) cama.admin@anu.edu.au

\section{ISSN 2206-0332}

The Centre for Applied Macroeconomic Analysis in the Crawford School of Public Policy has been established to build strong links between professional macroeconomists. It provides a forum for quality macroeconomic research and discussion of policy issues between academia, government and the private sector.

The Crawford School of Public Policy is the Australian National University's public policy school, serving and influencing Australia, Asia and the Pacific through advanced policy research, graduate and executive education, and policy impact. 


\title{
The Industrial Impact of Economic Uncertainty Shocks in Australia
}

December 2019

\author{
Hamish Burrell ${ }^{\mathrm{a}}$, Joaquin Vespignani ${ }^{\mathrm{a}, \mathrm{b}}$ \\ a Tasmanian School of Business and Economics, University of Tasmania, Australia \\ ${ }^{\mathrm{b}}$ Centre for Applied Macroeconomic Analysis, Australian National University, Australia
}

\begin{abstract}
This study establishes the first empirical evidence of the impact of economic uncertainty shocks on industry-level investment, output and employment in Australia. We find the Construction and Financial and Insurance Services industries are the most impacted by a shock to economic uncertainty. Statistically significant declines are observed for investment, output and employment in the Construction industry, and in terms of magnitude, the declines in output and employment are the largest across all industries studied. Likewise, the Financial and Insurance Services industry experiences declines across investment, output and employment, and undergoes the largest decline in investment in comparison to all other industries examined. Economic uncertainty explains the most substantial portion of the variation in Financial and Insurance Services investment and output, highlighting the detrimental effect it has on the Financial and Insurance Services industry. Furthermore, Health Care and Social Assistance output and Professional, Scientific and Technical Services investment experience considerable declines, and in contrast, Public Administration and Safety is shown to be the least impacted industry.
\end{abstract}

Keywords: Economic Uncertainty, Economic Uncertainty Shocks, SVAR, Australian economy, Australian Industries

JEL classification: C10, C32, E00, E30

Corresponding author: Joaquin Vespignani; Tasmanian School of Business and Economics, University of Tasmania, Australia; E-mail address: Joaquin.Vespignani@utas.edu.au 


\section{INTRODUCTION}

This paper aims to uncover the impact of economic uncertainty shocks on industrial: investment, output and employment. In terms of defining uncertainty, this paper follows the definition set out by Moore (2017, p. 550), whereby, uncertainty refers to 'clarity, or lack thereof, about future economic activity', which integrates both 'risk' and 'Knightian uncertainty'. ${ }^{1}$

The literature related to economic uncertainty has significantly expanded during the past 10 years. However, economic uncertainty is generally studied at an aggregate level, rather than at an industrial (dis-aggregated) level, leaving a significant gap in the growing literature. ${ }^{2}$ The influential study by Bloom (2009) has prompted discussion about the empirical results of uncertainty shocks, since his study it is heavily documented that an unexpected, temporary economic uncertainty shock causes aggregate investment, output, and employment to decline for an economy (Caggiano, Castelnuovo \& Groshenny, 2014; Baker, Bloom \& Davis, 2016; Gieseck \& Largent 2016; Moore 2017). However, this response is of varying magnitude and in some instances overshooting of the impulse response function occurs. This well-acknowledged response to an uncertainty shock may not be the case for specific industries within an economy, as magnitude and direction may be industry-dependent.

Denis \& Kannan (2013), highlight the vital role in which empirical results help design policy framework in response to heightened economic uncertainty, particularly during downturns. Additionally, Bloom (2014) discuss how policymakers are interested in the dynamics of uncertainty responses, because a short, sharp response of output to an uncertainty shock may require an equally short, sharp macroeconomic stimulus to achieve stabilisation. The empirical findings in this paper will help guide policymakers of the dynamic responses of

\footnotetext{
${ }^{1}$ As outlined by Moore (2017), 'risk' reflects the probabilities of potential outcomes being known, but the outcome which occurs is unknown. Whereas, 'Knightian uncertainty’ reflects neither the probabilities of outcomes and the outcomes themselves are known.

${ }^{2}$ Examples of aggregate-level studies include: Bloom (2009), Dennis \& Kannan (2013), Caggiano, Castelnuovo \& Groshenny, (2014), Gieseck \& Largent (2016), Sorić \& Lolić (2017), Moore (2017), Cerda, Silva \& Valente, (2018) and Istiak \& Serletis (2018).
} 
Australian industries to economic uncertainty shocks. Allowing for public policy to become more adaptable to individual industries, which is crucial, particularly when the relative size of Australian industries is frequently shifting. The Manufacturing industry, which previously comprised of 12 per cent of the total economy in 1987:2 is rapidly declining, only accounting for 6 per cent in 2018:4. While other industries such as Health Care and Social Assistance, Mining, and Financial and Insurance Services, which comprised of 5, 5 and 6 per cent of the total economy in 1987:2 are significantly expanding to account for 7, 8 and 9 per cent in 2018:4.

There are many different proxies to measure the level of uncertainty for an economy. More traditionally, finance-based proxies and forecaster disagreement between macroeconomic variables were commonly used to measure uncertainty. In more recent years, newspaper-based measures of uncertainty have become increasingly popular in the literature; Baker, Bloom \& Davis, (2016) develops newspaper-based economic policy uncertainty indexes for numerous countries, including Australia. Expanding on from this index, Moore (2017) constructs a more conceptually broad economic uncertainty index for Australia, which is used in this study to measure economic uncertainty for Australia. This index is a weighted average of four uncertainty measures: newspaper-based uncertainty, forward-looking stock market volatility, analyst earning forecast uncertainty and gross domestic product (GDP) growth forecast dispersion. $^{3}$

The index comprises of a longer time frame in comparison to that of the economic policy uncertainty index and covers a more broad range of uncertainty, which may be more appropriate for Australia, being a small open economy (Moore 2017).

Figure 1 presents the Australian economic uncertainty index; key events (both of a domestic and international nature) which are intuitively expected to alter the level of economic uncertainty in Australian are linked to the index, which is an adaption from Moore (2017). Being able to align these events is reassuring that the index appropriately captures economic

\footnotetext{
${ }^{3}$ For a description of each type of uncertainty and their relative weights, refer to Moore (2017), pages 551-556.
} 
uncertainty (Moore 2017). The index is shown to identify both domestic events, as well as international events, which are applicable due to the small open nature of the Australian economy.

To quantify the impact of economic uncertainty shocks on Australian industries, this study will use a structural vector autoregression (SVAR) model, based upon current Australian and international literature, while also incorporating industry-specific methods. This paper develops three separate models, each containing a different industry measure (either investment, output or employment).

This is the first paper to analyse the impact of economic uncertainty shocks on Australian industrial: investment, output, and employment, and introduces a measure of economic uncertainty into the Australian SVAR model. The industries which are of focus in this study are chosen based on their relative size to the total economy and data availability, the seven largest industries in Australia as of 2018:4 are chosen. These include: Financial and Insurance Services (9\%), Mining (8\%), Construction (8\%), Health Care and Social Assistance (7\%), Professional, Scientific and Technical Services (7\%) Manufacturing (6\%) and Public Administration and Safety (5\%), this study also examines the sub-industries of the mining and manufacturing industries. ${ }^{4}$

The key finding of this study is that the Construction and Financial and Insurance Services industries are the most impacted by an economic uncertainty shock. All three industry measures in the Construction industry are shown to decline in response to an economic uncertainty shock, which may reflect the industries reliance on financing when undertaking investment projects. In terms of magnitude, the declines in Construction output and employment are the largest across all industries studied. Similarly, the Financial and Insurance

\footnotetext{
${ }^{4}$ The number adjacent to each industry indicate the relative size of that industry compared to the total economy, in percentage. Overall these seven industries comprise of 50 per cent of the total Australian economy. Ideally, the sub-industries of Construction and Financial and Insurance Services and Professional, Scientific and Technical Services would also be analysed; however, the data does not commence until 1994:3. Furthermore, Health Care and Social Assistance, and Public Administration and Safety are not disaggregated into subindustries.
} 
Services industry is shown to experience declines across all three industry measures and undergoes the largest decline in investment out of all other industries. This may reflect the ability of the Financial and Insurance industry to rapidly respond to news and other economic uncertainty events, which cause firms to reassess their investment activates in a much faster time frame in comparison to other industries.

Mining investment experiences a smaller decline in comparison to a majority of the other industries, the subdued response of Mining investment may be attributed to the long-term investment nature of the industry, meaning a temporary shock to uncertainty today is likely to have little impact on Mining investment decisions in the present. In contrast, Public Administration and Safety is shown to be the least impacted industry, which may reflect the government nature of this industry, whereby employment is relatively more fixed and the industry as a whole is unable to readily adjust employment decisions in response to an economic uncertainty shock.

The paper proceeds as follows. Section 2 provides a review of existing uncertainty theory and current empirical evidence of the impact of economic uncertainty shocks on macroeconomic variables. Section 3 outlines the data description, SVAR methodology, identification restrictions, and model functional form. Section 4 presents the results of economic uncertainty shocks on industry output, investment and employment in terms of impulse response functions and variance decompositions. Section 5 provides a detailed robustness analysis and Section 6 concludes.

\section{LITERATURE REVIEW}

This section outlines the existing theory and empirical literature to gain a better understanding of the role that economic uncertainty plays on the macroeconomy and how economic uncertainty shocks impact key macroeconomic indicators such as output, investment and employment. There are several avenues through which uncertainty impacts macroeconomic performance; these theories are extensively studied and outlined in the literature. 
The relationship between uncertainty and investment decisions has been established by several important contributions (Bernanke 1983; Bloom 2009). These studies argue that there is value in waiting for increased information when agents are making decisions which are costly to reverse, such as investment (and hiring). Establishing what is known as the 'real-options' channel of uncertainty, which predicts an initial decline in investment and employment in response to a temporary increase in uncertainty, following the initial uncertainty shock, firms realise their demand for capital and labour, causing both investment and employment to rebound and overshoot.

Bloom (2014) highlights that an increase in savings is likely to depress economic activity in the short-run; however, the impact in the long-run is not as well-defined. Since, lower consumption and higher savings may translate into a higher investment level, which may positively impact long-run growth.

Bloom (2014) emphasises that investors want to be compensated for absorbing higher risk and since heightened uncertainty raises the risk premia, the cost of finance should increase as well ('risk premia' channel of uncertainty). Raising the cost of finance can reduce both microeconomic and macroeconomic growth.

Although much of the current uncertainty theories highlight the detrimental impact economic uncertainty can pose for an economy, Bloom (2014) discusses two channels in which uncertainty can have a positive effect on long-run growth. Firstly, the 'growth options', which is based on the premise that uncertainty can encourage investment if it increases the size of the potential return. Secondly, the 'Oi-Hartman-Abel effect', which highlights that if firms can expand to exploit good outcomes and can contract to insure themselves against adverse outcomes, then they may be risk-loving. ${ }^{5}$

The relationship between economic uncertainty and industrial: investment, output and employment, is understudied worldwide and currently unexplored in Australian literature.

\footnotetext{
${ }^{5}$ However, for the second theory to function, firms need to be able to readily expand or contract in response to good or bad news.
} 
Consequently, the remaining paragraphs outline empirical evidence of economic uncertainty shocks on the broader macroeconomy to gain an understanding of the current empirical findings and what may be expected at the industrial level. Table A.1, in Appendix A, summarises the authors, proxy of uncertainty, countries, methodology and sample period for each paper discussed in this section.

In his prominent paper, Bloom (2009) conducts one of the first empirical analyses to uncover the relationship between uncertainty and the macroeconomy. He establishes that output and employment experience a rapid decline, followed by a recovery and overshoot from a temporary unexpected uncertainty shock.

Using his economic uncertainty index for the Australian economy Moore (2017) develops two VAR models to establish the consequences of heightened economic uncertainty on the Australian economy. ${ }^{6}$ Consistent with the 'real options' channel, a shock to economic uncertainty reduces machinery and equipment investment and employment growth in Australia; however, no evidence of overshooting is observed.

Baker, Bloom \& Davis, (2016) conducts two analyses using their economic policy uncertainty indexes for numerous countries. Firstly, using a microeconomic estimation approach with firm-level regressions, they find that the investment rate and employment growth decline when economic policy uncertainty rises. Secondly, they employ two models, a VAR using U.S data and a 12-country panel VAR, both establish a decline in gross investment, industrial production and employment in response to an economic policy uncertainty shock.

Kang, Lee \& Ratti, (2014) find that when firms are in doubt of policy factors, they become more cautious of their investment decisions; however, the impact of economic policy uncertainty is much more negligible on large firms. Furthermore, examining fixed firm investment of listed and delisted non-financial companies on the Australian stock exchange,

\footnotetext{
${ }^{6}$ The first model uses a monthly frequency and the second model uses a quarterly frequency.
} 
Tran (2014) finds a negative relationship between investment and uncertainty and that financially constrained firms are more sensitive to uncertainty.

From a time-series perspective, Gulen \& Ion (2016) and Gieseck \& Largent (2016) uncover that a shock to economic uncertainty depresses investment, as investment is observed to experience a rapid drop and rebound, and in the case of Gulen \& Ion (2016), overshooting occurs, which is consistent with the 'real options' channel. Additionally, Gulen \& Ion (2016) find that firms operating in industries with a high dependence on government spending are considerably more impacted by economic policy uncertainty shocks. Similarly, CarrièreSwallow \& Céspedes (2013) establish that economic uncertainty shocks cause a rapid drop and rebound in investment for both developing and emerging countries, while Meinen \& Roehe (2017) find that periods of low or negative investment growth in the four largest euro-area countries can be explained in part by increased economic uncertainty, emphasising its impact on the macroeconomy.

Denis \& Kannan (2013), Gieseck \& Largent (2016) and Istiak \& Serletis (2018) outline that a temporary economic uncertainty shock depresses economic activity (real GDP and/or industrial production), causing a rapid decline, which soon after rebounds, establishing a consistent empirical relationship which complements the findings of Bloom (2009) and Baker, Bloom \& Davis, (2016) as previously discussed.

Caggiano, Castelnuovo \& Groshenny, (2014) discover when an economic uncertainty shock is applied to a linear VAR, the rise in unemployment is more subdued compared to the same shock being applied to a non-linear VAR, indicating the response is more severe during recessionary periods. Additionally, the authors find that both output and investment undergo rapid drops, followed by overshooting to a temporary economic uncertainty shock, which is more sensitive when using a non-linear VAR. ${ }^{7}$ In comparison, Caggiano, Castelnuovo \&

\footnotetext{
${ }^{7}$ They argue that linear models mixing up recessions and non-recessionary periods may significantly reduce the effects of an economic uncertainty shock on the macroeconomy.
} 
Nodari, (2017) find similar evidence that the responses of real activity indicators are more sensitive when economic uncertainty shocks occur in a recessionary period.

In addition to Baker, Bloom \& Davis, (2016), several studies create unique and countryspecific indexes to proxy for economic uncertainty and use these indexes to analyse the impact of economic uncertainty on their respective country.

Girardi \& Reuter (2017) present three new proxy measures for uncertainty for the Euro Area, finding their measures of uncertainty produce a temporary reduction in GDP when a shock is applied to a VAR model. Similarly, Sorić \& Lolić (2017) introduce a set of economic uncertainty indicators for the Croatian economy, establishing that on average, an economic uncertainty shock causes a temporary negative impact on economic activity, and this response becomes more pronounced in the contractionary phases of the business cycle. Cerda, Silva \& Valente, (2018) construct the first news-based economic uncertainty index for Chile. Accounting for Chile's small open economy nature, they find a shock to economic uncertainty generates an immediate positive response, followed by a sudden decline in Chilean investment, a majority of this decline is attributed to private investment. Additionally, economic uncertainty shocks depress Chilean GDP and employment.

Phan, Sharma \& Tran, (2018) examine whether economic policy uncertainty is a predictor of excess stock returns, finding that predictability, and economic significance is sector-dependent. Additionally, Hu, Kutan \& Sun, (2018) establish that industries display different levels of sensitivity in China's A-shares market to shocks in the United States (U.S) economic policy uncertainty. Although these studies do not analyse the impact of economic uncertainty on industrial: investment, output and employment, they highlight that economic uncertainty shocks are likely to have unique impacts on different industries.

The empirical literature discussed in this section establishes a consistent theme, whereby, economic uncertainty shocks induce a rapid decline in investment, output and 
employment at an aggregate level, which rebounds soon after and in some cases is documented to overshoot.

\section{MODEL AND DATA DESCRIPTION}

This study aims to quantify the effect of economic uncertainty shocks on Australian industries using a structural VAR model. VAR models are common in the literature to analyse the relationship between economic uncertainty and activity. ${ }^{8}$ Generally Australian SVAR studies assume that Australia is a small open economy which cannot influence the world economic conditions, this assumption is maintained by introducing separate domestic and foreign blocks of variables in the model (Dungey \& Pagan 2000). This study builds on the current Australian SVAR models by introducing a measure of economic uncertainty for Australia.

This study develops three separate models, each containing a different industry measure (either investment, output or employment). In-line with previous industrial Australian SVAR studies (Lawson \& Rees 2008; Vespignani 2013; Knop \& Vespignani 2014; Manalo, Perera \& Rees, 2015), the models are estimated one industry at a time.

A model containing all industry variables would be ideal; however, this is not possible due to the trade-off of remaining parsimonious. A single model would require three additional industry variables to be introduced (in addition the lags of those variables), in addition to the other domestic and foreign variables already present, significantly reducing the degrees of freedom, which is problematic when using low frequency (quarterly) observations. ${ }^{9}$ Creating three separate models does however have disadvantages, whereby a potential misspecification issue may arise and important interactions between the industry variables may be lost. Although there are drawbacks to this method, it allows us to gauge the general direction and magnitude of all industry measures and to see if there are similarities between responses in each industry,

\footnotetext{
${ }^{8}$ For example: Bloom (2009), Baker, Bloom \& Davis, (2016), Girardi \& Reuter (2017), Sorić \& Lolić (2017).

${ }^{9}$ The additional industry variables which will need to be included are $G V A_{-i t}, I N D_{-i t}$, and $E M P_{-i t}$ (these variables are defined and discussed in Section 3.2).
} 
as well as alleviate the concerns of reducing the degrees of freedom. Sections 3.1 and 3.2 outline the variables which are included in the models, for further detail, refer to Table A.2, in Appendix B.

\subsection{Foreign Variables}

The foreign block captures the influence of global economic developments on Australian economic conditions. The following variables represent the global economy, Australian terms of trade $\left(T O T_{t}\right)$, the Australian index of commodity prices $\left(C O M_{t}\right)$, real world GDP $\left(W G D P_{t}\right)$, the world inflation rate $\left(W I N F_{t}\right)$, and the world short-term interest rate $\left(W I N T_{t}\right)$ into the models.

Overtime Australian studies have considered alternative approaches to represent the foreign economy. Traditionally, U.S variables, such as U.S GDP, inflation and interest rate are incorporated to measure the global economy. ${ }^{10}$ In addition, Dungey \& Pagan (2000), Vespignani (2013) and Manalo, Perera \& Rees, (2015) introduce the Australian terms of trade to control for changes in the trade conditions of the Australian economy resulting from external factors, whereas, Lawson \& Rees (2008), Jacobs \& Rayner (2012) and Dungey et al. (2017) include the Australian commodity price index to account for Australia's high dependence on commodity prices.

Compositions of the global economy are constantly changing, and as such, the significance of one country may shift over time. Consequently, Jacobs \& Rayner (2012), Jääskelä \& Smith (2013), Dungey, Fry-Mckibbin \& Linehan, (2014) and Dungey et al. (2017) use an export-weighted quarterly real GDP growth of Australia's major trading partners as a measure of foreign output. Similarly, Knop \& Vespignani (2014) develop proxies for the world economy using Australia's five largest trading partners, but instead of being export-weighted, they use total trade-weights.

\footnotetext{
${ }^{10}$ For example: Dungey \& Pagan (2000), Berkelmans (2005), Claus, Dungey \& Fry, (2008), Liu (2010), Jääskelä and Jennings (2011), Vespignani (2013) and Manalo, Perera \& Rees, (2015).
} 
Figure 2 shows Australia’s largest trading partners using total (two-way) trade value from 1987 to 2018. It can be seen that China has a significantly growing importance for Australian trade, comparatively to that of the U.S and Japan. ${ }^{11}$ Consistent with modern literature, Australia's major trade partners; China, Japan, U.S, Euro Area and the Republic of Korea proxy for the world economy. Following Knop \& Vespignani (2014), we construct $W G D P_{t}$ through aggregating the real GDP (in U.S dollars) of Australia's major trade partners. Whereas, we develop proxies for $W I N F_{t}$ and $W I N T_{t}$ by aggregating the central bank policy rate and the quarterly change of the consumer price index of each major trade partner and weighting by total trade value. ${ }^{12}$

\subsection{Domestic Variables}

In-line with Berkelmans (2005), Knop \& Vespignani (2014) and Dungey et al. (2017), real Australian GDP $\left(A G D P_{t}\right)$ represents domestic output. Consistent with Jääskelä \& Jennings (2011), Dungey, Fry-McKibbin \& Linehan, (2014), and Dungey et al. (2017) real non-farm GDP is used rather than real GDP since real farm GDP can suffer from short-term volatility due to extreme weather events.

When analysing specific industries, it is a common practice to include both the industry being analysed and all other industries in the economy, which allows interaction between the two to occur. This method is first used by Lawson \& Rees (2008), then adopted by Vespignani (2013), Knop \& Vespignani (2014) and Manalo, Perera \& Rees, (2015), and is incorporated here by introducing the following variables. Firstly, when considering industry output (real gross value added (GVA)), $A G D P_{-i t}$ is defined as the real Australian non-farm GDP minus the real GVA of industry $i\left(G V A_{i t}\right)$. Secondly, when considering industry investment (private new capital expenditure), which is represented by the abbreviation $I N V_{i t}, I N V_{-i t}$ is defined as total

\footnotetext{
${ }^{11}$ On average, during the entire sample period, these five countries comprise of 52 per cent of Australia's total trade value.

12 The trade-weights are adjusted to sum to one.
} 
investment minus the investment of industry $i .{ }^{13}$ Lastly, when considering industry employment (employed persons by industry division of main job), which is represented by the abbreviation $E M P_{i t}, E M P_{-i t}$ is defined as total employment minus the employment of industry $i$.

We include the trimmed mean consumer price index in quarterly change $\left(I N F_{t}\right)$ as a measure of relative prices in Australia, which follows Lawson \& Rees (2008), Dungey, FryMcKibbin \& Linehan, (2014), Manalo, Perera \& Rees, (2015), and Dungey et al. (2017). The inclusion of inflation as a rate compared to a price level is consistent with a majority of Australian studies. ${ }^{14}$

The Australian short-term policy rate $\left(I N T_{t}\right)$ represents the stabilisation policy action undertaken by the Reserve Bank of Australia, and the Australian trade-weighted index $\left(T W I_{t}\right)$ is a measure of the real exchange rate. Lawson \& Rees (2008) outline the trade-weighted index as an important macroeconomic variable due to its influence on Australia's trade flows. The inclusion of both variables is common across Australian SVAR studies.

Unlike previous Australian SVAR studies, the Australian index of economic uncertainty $\left(U N C E R_{t}\right)$ is an addition in the domestic block of variables as a measure of Australian economic uncertainty. Economic uncertainty is an important inclusion in international studies to explain macroeconomic behaviour (Bloom 2009; Baker, Bloom \& Davis, 2016; Cerda, Silva \& Valente, 2018), and Castelnuovo, Lim \& Pellegrino, (2017) outline how uncertainty may be a potential cause and/or consequence of the business cycle.

\footnotetext{
${ }^{13}$ Private new capital expenditure measures new capital expenditure by private businesses for Australian industries, excluding Public Administration and Safety. Furthermore, Health Care and Social Assistance was not included in the survey until June 2018 (ABS Cat No. 5625.0, Explanatory Notes). Consequently, Public Administration and Safety, and Health Care and Social Assistance are excluded from this analysis.

${ }^{14}$ For example: Dungey \& Pagan (2000), Berkelmans (2005), Claus, Dungey \& Fry, (2008), Jääskelä \& Smith (2013), Vespignani (2013), Knop \& Vespignani (2014) and Manalo, Perera \& Rees, (2015).
} 


\subsection{Methodology}

The methodology builds upon and follows both existing Australian and international literature, incorporating industry-specific methods. ${ }^{15}$ We assume the following structural form equation represents the Australian economy (ignoring any constant terms in the model):

$$
B_{0} X_{t}=B(L) X_{t-1}+K(L) Y_{t}+\varepsilon_{t}
$$

$B_{0}$ is an $n \times n$ matrix which is normalised to have ones on the diagonal to allow each equation in the SVAR model to have a dependent variable, while the off-diagonal elements summarise the contemporaneous relationships between the variables in the vector $X_{t}$ (a $n \times 1$ vector of the endogenous (domestic) variables). $Y_{t}$ is a $n \times 1$ vector of the exogenous (foreign) variables. $\varepsilon_{t}$ is a $n \times 1$ vector that contains orthogonal structural disturbances and follows the assumptions: $E\left(\varepsilon_{t} \varepsilon_{t+s}^{\prime}\right)=0 \forall s \neq 0$ and $E\left(\varepsilon_{t} \varepsilon_{t}^{\prime}\right)=D . D$ is the diagonal variance-covariance matrix of $\varepsilon_{t}$, which has zeros on the off-diagonal elements and contains the variances of the structural shocks on the diagonal. $B(L)$ and $K(L)$ are matrices which summarise the lag structure of the variables in the vectors $X_{t}$ and $Y_{t}$.

Due to the endogenous nature of the $X_{t}$ vector, estimation of the SVAR requires a twostep process in order to recover consistent estimates of the $B_{0}$ and $D$ matrices; firstly the following reduced-form VAR must be estimated:

$$
X_{t}=A(L) X_{t-1}+J(L) Y_{t}+u_{t}
$$

Where $A(L)=B_{0}^{-1} B(L), J(L)=B_{0}^{-1} K(L)$ and $u_{t}$ is a $n \times 1$ vector of serially uncorrelated reduced-form shocks, which has the following properties: $E\left(u_{t} u_{t+s}^{\prime}\right)=0 \forall s \neq$ 0 and $E\left(u_{t} u_{t}^{\prime}\right)=\Sigma$. If the variables in the model are correlated, the reduced-form residuals are often correlated as well. Consequently, it is not possible to accurately gauge the impact of an individual shock via the impulse response function from the reduced-form VAR.

\footnotetext{
${ }^{15}$ For example: Dungey \& Pagan (2000), Jacobs \& Rayner (2012), Dungey, Fry-McKibbin \& Linehan, (2014), Jääskelä \& Smith (2013), Bloom (2009), Baker, Bloom \& Davis, (2016), Cerda, Silva \& Valente, (2018) Lawson \& Rees (2008), Knop \& Vespignani (2014) and Manalo, Perera \& Rees (2015).
} 
The structural shocks and the reduced-form residuals are related such that $B_{0} u_{t}=\varepsilon_{t}$, implying the covariance-variance matrix of errors of the structural form is given by:

$$
E\left(\varepsilon_{t} \varepsilon_{t}^{\prime}\right)=E\left(B_{0} u_{t} u_{t}^{\prime} B_{0}^{\prime}\right)=D
$$

To recover the structural parameters specified in Equation (1), the models must be either exactly or over-identified, which requires there to be at least the same number of parameters in

$B_{0}$ and $D$ as there are in $\Sigma$; therefore, at least $\frac{n(n-1)}{2}$ restrictions are required. The subsequent stage of the SVAR estimation requires placing sufficient restrictions on the $B_{0}$ and $D$ matrices. Fry \& Pagan (2011) highlight there are five methods in the SVAR literature to impose adequate restrictions on the model, one of which is placing zero restrictions on the $B_{0}$ matrix to recover the endogenous variables in the structural equations, which is undertaken in this study.

To develop a theoretically accurate model, restrictions can be guided by economic theory and empirical findings to outline the relationships between the variables, this approach is known as an SVAR and is used to generate impulse response functions and variance decompositions, which are discussed later in Section 4.

Note, as Baker, Bloom \& Davis, (2016) discuss, drawing causal inferences from VARs can be challenging, particularly when economic uncertainty is an inclusion since it responds to current and future economic events. However, they outline, that at a minimum, VARs can assess whether economic uncertainty shocks weaken macroeconomic performance and are useful to establish dynamic relationships.

\subsection{Identification Restrictions}

In-line with the small open economy assumption, the foreign block of variables is are strictly exogenous, meaning the domestic block cannot influence the global economy, which is in-line Jacobs \& Rayner (2012), Vespignani (2013) and Knop \& Vespignani (2014).

The following paragraphs discuss the contemporaneous restrictions applied to the $B_{0}$ matrix in equation (1). Firstly, a general set of restrictions will be discussed in the paragraphs below, which will apply to every model, subsequently, Sections 3.4.1, 3.4.2 and 3.4.3 outline 
how the industry-specific variables are then incorporated within the general restrictions, creating three separate models.

We order $U N C E R_{t}$ first out of the domestic block variables, this allows $U N C E R_{t}$ to contemporaneously impact all domestic block variables, this approach is consistent with a majority of international VAR uncertainty literature. ${ }^{16}$ The ordering of uncertainty is investigated further in Section 5.

$A G D P_{t}$ precedes $U N C E R_{t}$ in the ordering of the domestic block variables, therefore, $U N C E R_{t}$ contemporaneously impacts $A G D P_{t}$. This ordering is consistent with several Australian studies (Berkelmans 2005; Lawson \& Rees 2008; Knop \& Vespignani 2014), which order Australian output first out of the domestic block variables. ${ }^{17}$

$I N F_{t}$ responds contemporaneously to Australian output, which follows Dungey \& Pagan (2000), Berkelmans (2005), Lawson \& Rees (2008) and Knop \& Vespignani (2014), and $U N C E R_{t}$, as previously mentioned. $I N F_{t}$ is not contemporaneously impacted by $I N T_{t}$, since changes in the interest rate take considerably longer to impact consumption and investment decisions, and therefore flow through to prices (Knop \& Vespignani 2014). Following Jacobs \& Rayner (2012), $I N F_{t}$ is not immediately impacted by $T W I_{t}$, since the pass-through of exchange rate movements to overall consumer prices occurs gradually over time (Chung, Kohler \& Lewis, 2011).

There are two conventional methods in the literature on specifying the contemporaneous restrictions of the domestic interest rate equation; Knop \& Vespignani (2014) concisely outline both methods. One of which involves specifying a Taylor type monetary policy rule, which allows domestic output and inflation to contemporaneously impact the domestic interest rate,

\footnotetext{
${ }^{16}$ For example: Bloom (2009), Caggiano, Castelnuovo \& Groshenny, (2014), Baker, Bloom \& Davis, (2016), Gieseck \& Largent (2016), Girardi \& Reuter (2017), Sorić and Lolić (2017) and Cerda, Silva \& Valente, (2018). Bloom (2009) orders the S\&P 500 stock market index before uncertainty.

${ }^{17}$ Knop \& Vespignani (2014) order commodity prices prior to domestic output; however, commodity prices are included in the foreign block for this study.
} 
which this study follows. This method is in-line with Dungey \& Pagan (2000), Dungey, FryMcKibbin \& Linehan, (2014) and Knop \& Vespignani (2014).

We order $T W I_{t}$ last in the domestic block of variables, meaning it responds contemporaneously to all other domestic variables, which is standard across Australian SVAR literature. The reason for this restriction is that exchange markets respond rapidly to all available (domestic and international) information (Vespignani 2013).

In terms of the foreign variables, $W G D P_{t}, C O M_{t}$ and $T O T_{t}$ contemporaneously affect the domestic block variables. Allowing contemporaneous interaction between $W G D P_{t}$ and $C O M_{t}$ to the domestic block variables follows Dungey \& Pagan (2000), Lawson \& Rees (2008), Dungey, Fry-McKibbin \& Linehan, (2014) and Dungey et al. (2017), whereas, allowing TOT to immediately impact the domestic block variables is consistent with Dungey \& Pagan (2000) and Vespignani (2013). Vespignani (2013) outlines that these interactions are valid since domestic economic agents can observe changes in international output, commodity prices and the exchange rate in the same quarter.

\subsubsection{Output Model}

In addition to the restrictions applied in Section 3.4, $G V A_{i t}$ precedes $A G D P_{-i t}$ in the ordering, meaning $G V A_{i t}$ is contemporaneously impacted by $A G D P_{-i t}$ and $U N C E R_{t}$. Ordering $G V A_{i t}$ after $A G D P_{-i t}$ is consistent with other Australian industrial studies (Lawson \& Rees 2008; Vespignani 2013; Knop \& Vespignani 2014). Knop \& Vespignani (2014) argue the reason for this sequencing is because each industry comprises of only a small portion of the total economy, hence, the remaining industries of the economy will have a flow-on effect in the same quarter.

$I N F_{t}$ responds contemporaneously to Australian output, which also includes $G V A_{i t}$; consistent with Lawson \& Rees (2008) and Knop \& Vespignani (2014). In-line with Vespignani (2013) and Knop \& Vespignani (2014), GVA $A_{i t}$ does not contemporaneously impact $I N T_{t}$, and 
following the discussion in Section 3.4, GVA $A_{\text {it }}$ contemporaneously impacts $\mathrm{TWI}_{\mathrm{t} .}{ }^{18}$ Equation 4 summarises the contemporaneous restrictions between the domestic block for the output model; each non-zero bij coefficient indicates that variable j affects variable i contemporaneously.

$$
B_{0} X_{t}=\left[\begin{array}{cccccc}
1 & 0 & 0 & 0 & 0 & 0 \\
b_{21} & 1 & 0 & 0 & 0 & 0 \\
b_{31} & b_{32} & 1 & 0 & 0 & 0 \\
b_{41} & b_{42} & b_{43} & 1 & 0 & 0 \\
b_{51} & b_{52} & 0 & b_{54} & 1 & 0 \\
b_{61} & b_{62} & b_{63} & b_{64} & b_{65} & 1
\end{array}\right] *\left[\begin{array}{c}
U N C E R_{t} \\
\Delta \log \left(A G D P_{-i t}\right) \\
\Delta \log \left(G V A_{i t}\right) \\
I N F_{t} \\
I N T_{t} \\
\Delta \log \left(T W I_{t}\right)
\end{array}\right]
$$

\subsubsection{Investment Model}

The investment model follows similar contemporaneous interactions as set out in the Output Model in Section 3.4.1.

Following the argument of Vespignani (2013) and Knop \& Vespignani (2014), $I N V_{\text {-it }}$ is ordered prior to $I N V_{i t}$ since $I N V_{i t}$ is too small to impact $I N V_{\text {-it }}$; hence, $I N V_{\text {-it }}$ will have a flow-on effect in the same quarter. There is no previously introduction of investment in an Australian SVAR study; thus, there is no Australian context to base the ordering of the investment variables. Consequently, to be consistent with the estimation of the Output Model (Section 3.4.1), which is based on well-established relationships in the literature, we order both investment variables after $A G D P_{t}$ (prior to $I N F_{t}, I N T_{t}$ and $T W I_{t}$ ), and following Vespignani (2013) and Knop \& Vespignani (2014) the industry variable does not contemporaneously impact $I N T_{t}$, which is outlined in Equation 5. The ordering is further examined in the Robustness Analysis in Section 5.

$$
B_{0} X_{t}=\left[\begin{array}{ccccccc}
1 & 0 & 0 & 0 & 0 & 0 & 0 \\
b_{21} & 1 & 0 & 0 & 0 & 0 & 0 \\
b_{31} & b_{32} & 1 & 0 & 0 & 0 & 0 \\
b_{41} & b_{42} & b_{43} & 1 & 0 & 0 & 0 \\
b_{51} & b_{52} & b_{53} & b_{54} & 1 & 0 & 0 \\
b_{61} & b_{62} & b_{63} & 0 & b_{65} & 1 & 0 \\
b_{71} & b_{72} & b_{73} & b_{74} & b_{75} & b_{76} & 1
\end{array}\right] *\left[\begin{array}{c}
U N C E R_{t} \\
\Delta \log \left(A G D P_{t}\right) \\
\Delta \log \left(I N V_{-i t}\right) \\
\Delta \log \left(I N V_{i t}\right) \\
I N F_{t} \\
I N T_{t} \\
\Delta \log \left(T W I_{t}\right)
\end{array}\right]
$$

\footnotetext{
18 The sub-industries of mining and manufacturing are assumed to undergo the same contemporaneous restrictions applied to $G V A_{i t}$.
} 


\subsubsection{Employment Model}

The employment Model follows similar contemporaneous interactions as set out in the Output and Investment Models (Sections 3.4.1 and 3.4.2). Once again, following the argument of Vespignani (2013) and Knop \& Vespignani (2014), EMP-it is ordered prior to EMP it since $E M P_{-i t}$ is too small to impact $E M P_{-i t}$; hence, $E M P_{-i t}$ will have a flow-on effect in the same quarter.

Likewise, as with investment, there is no previous incorporation of employment in an Australian SVAR study, hence, there is no Australian context to base the ordering. Following the discussion in Section 3.4.2, to maintain consistency with the well-established Output Model, we order $E M P_{-i t}$ and $E M P_{i t}$ third and fourth out of the domestic block variables, and the industry variable does not contemporaneously impact $I N T_{t}$, which is outlined in Equation 6. The ordering is further examined in the Robustness Analysis in Section 5.

$$
B_{0} X_{t}=\left[\begin{array}{ccccccc}
1 & 0 & 0 & 0 & 0 & 0 & 0 \\
b_{21} & 1 & 0 & 0 & 0 & 0 & 0 \\
b_{31} & b_{32} & 1 & 0 & 0 & 0 & 0 \\
b_{41} & b_{42} & b_{43} & 1 & 0 & 0 & 0 \\
b_{51} & b_{52} & b_{53} & b_{54} & 1 & 0 & 0 \\
b_{61} & b_{62} & b_{63} & 0 & b_{65} & 1 & 0 \\
b_{71} & b_{72} & b_{73} & b_{74} & b_{75} & b_{76} & 1
\end{array}\right] *\left[\begin{array}{c}
U N C E R_{t} \\
\Delta \log \left(A G D P_{t}\right) \\
\log \left(E M P_{-i t}\right) \\
\Delta \log \left(E M P_{i t}\right) \\
I N F_{t} \\
I N T_{t} \\
\Delta \log \left(T W I_{t}\right)
\end{array}\right]
$$

\subsubsection{Model Identification}

Given the restrictions in Equations 4 to 6, each model is over-identified since there is one more zero restriction than necessary to exactly identify the Output, Investment and Employment Models. The likelihood ratio test for over-identification is calculated for every model, in a majority of cases the null hypothesis is retained; therefore the models are in favour of the restrictions applied, refer to Table A.4, in Appendix C for the results. 


\subsection{Functional Form}

\subsubsection{Estimation Period and Choice of Lag Length}

This study estimates the models using quarterly data from 1987:2 to 2018:4; the total number of observations in the sample period is $\mathrm{T}=127$. The start date is chosen based on when the private new capital expenditure data for industries becomes available.

Specification of the SVAR model requires including the appropriate number of lags. Incorporating too many lags risks over-parameterisation, however, the introduction of too few lags may cause the residuals to not be white noise, and standard inference is not appropriate (Lawson \& Rees 2008). We consider the Akaike Information Criterion (AIC), Hannan-Quinn (HQ) and Bayesian Information Criterion (BIC) for each industry, using a maximum of eight lags (two years) to select the appropriate lag length for each of the three models. Generally, the AIC and HQ indicate two lags is appropriate and in contrast, the BIC suggests one lag; in some cases, the AIC recommends eight lags. ${ }^{19}$ Due to the inconsistency between the lag selection tests, we follow current literature to select an appropriate lag length; in-line with Dungey \& Pagan (2000), Berkelmans (2005), Lawson and Rees (2008) and Vespignani (2013), a lag length of $p=3$ is selected for all three models. ${ }^{20}$

\subsubsection{Stationary Properties}

Consistent with previous literature all variables are expressed in log form besides the interest and inflation rate variables, and $U N C E R_{t}$, which enters the model in levels, this is consistent with Bloom (2009), Baker, Bloom \& Davis, (2016) and Sorić and Lolić (2017). This paper follows the methods of Jääskelä \& Smith (2013), Vespignani (2013) and Knop \& Vespignani (2014), whereby, the variables which are non-stationary in log-levels but stationary in first difference are differenced, and the variables that are stationary in log-levels enter the model in levels. ${ }^{21}$

\footnotetext{
19 Please contact the authors is you require the detailed results.

20 The lag length is further examined in the robustness analysis in Section 5.

${ }^{21}$ The stability condition of every model was checked; in all cases, the Modulus is less than one and no roots lie outside the unit circle, satisfying the stability condition for all Models.
} 


\subsubsection{Tests for Stationarity, Autocorrelation and Heteroskedasticity}

To determine variable stationarity, we conduct the Augmented Dicky Fuller (ADF) and the Kwiatkowski-Phillips-Schmidt-Shin (KPSS) tests. ${ }^{22}$ The ADF and KPSS test results (Table A.5, in Appendix C) suggest that a majority of the variables are non-stationary in levels; only $U N C E R_{t}$ is supported by both tests to be stationary. There are conflicting stationarity results for the world interest rate and the domestic inflation rate variables; however, all 'rate' variables enter the model in levels, this also applies to the domestic interest rate and the foreign inflation rate, which are shown to be non-stationary. We once again conduct the ADF and KPSS tests on all non-stationary variables, now using the first difference (Table A.5, in Appendix C). Both tests indicate the remaining non-stationary variables are first difference stationary, which is generally at the one per cent level of statistical significance. ${ }^{23}$

The residual serial correlation LM Test is used to test of first-order serial correlation in the models, the null hypothesis of no first-order serial correlation cannot be rejected at the 5 per cent significance level for a majority of models. Similarly, we conduct the residual White Heteroskedasticity Test for each model; the null hypothesis of no heteroskedasticity cannot be rejected at the 5 per cent significance level in almost all models. ${ }^{24}$

\section{RESULTS}

This section outlines the empirical findings of this study; we use the impulse response function (IRF) to evaluate the impact of economic uncertainty shocks on industrial: investment, output and employment, in Australia, these results will help outline the dynamic response of industries. A temporary economic uncertainty shock is introduced to the models by applying a one standard deviation impulse to the economic uncertainty variable. ${ }^{25}$

\footnotetext{
${ }^{22}$ The null hypothesis of the ADF test is that the variable is non-stationary; in contrast, the null hypothesis of the KPSS test is that the variable is stationary.

${ }^{23}$ Please contact the authors is you require the detailed results.

${ }^{24}$ Please contact the authors is you require the detailed results.

${ }^{25}$ For all responses in this section, the solid black line represents the impulse response of each industry, and the dashed red lines represent the asymptotic standard error, in this study, one standard error is used which is consistent with Sorić and Lolić (2017). The vertical axis represents the percentage change, whereas the horizontal axis represents periods (quarters).
} 
Furthermore, this section also analyses the variance decomposition of each industry to examine the relative importance of the structural shocks, by outlining the proportion of variation in each industry variable that can be attributed to a structural shock to economic uncertainty. Additionally, Section 4.4 outlines the IRFs of the Australian aggregate economy to an economic uncertainty shock.

\subsection{Economic Uncertainty Shocks: Industries}

Figure 3 reports the IRF for each industry across the three models in response to a temporary economic uncertainty shock; each row represents the response of investment, output and employment for that particular industry.

Overall, Construction appears to be the most impacted industry to an economic uncertainty shock, showing statistically significant declines in investment, output and employment. As shown, both investment and output immediately decline, and at their respective peaks in the third and fourth quarters, fall roughly 3.6 and 0.4 per cent, becoming statistically significant. Employment displays a similar result; however, an immediate increase is observed, followed by a decline of 0.37 per cent in the second quarter which becomes statistically significant, emphasising the adverse impact economic uncertainty shocks have on the Construction industry. These responses may reflect the Construction industries reliance on financing when undertaking investment projects. As discussed in Section 2, heightened uncertainty causes the cost of financing to increase through the 'risk premia' channel, which may cause a reduction in investment within the industry, and flows through to lower output and employment.

In respect to industry investment, Financial and Insurance Services is the most impacted industry, the IRF documents an initial statistically significant increase in the first quarter, which is followed by a substantial decline of approximately 4.2 per cent in the second quarter, that is statistically significant for one period. The Financial and Insurance Services industry, (particularly financial investment) is incredibly responsive to news, and other related economic uncertainty events, causing businesses to readily adjust investment strategies in response to an 
economic uncertainty shock, this styled fact may help to explain why investment is observed to experience a substantial decline. Financial and Insurance Services output is shown to experience an initial (statistically significant) decline of approximately 0.24 per cent in response to an economic uncertainty shock, which follows that of investment, rebounding and overshooting in subsequent periods. Lastly, employment is shown to immediately increase, then decline below the baseline of zero; however, this response is statistically insignificant.

As shown, an economic uncertainty shock results in a small decline in Manufacturing investment, which is statistically significant during quarters three to six. Additionally, the Manufacturing industry experiences a decline of approximately 0.3 per cent in output, (which becomes statistically significant at its peak in the third quarter), and a decline of roughly 0.2 per cent in employment (which briefly becomes statistically significant at its peak in the fourth quarter). The three responses are generally consistent with the empirical findings discussed in Section 2, whereby, an economic uncertainty shock is shown to depress investment, output and employment. A possible reason for these responses is that an economic uncertainty shock has a greater impact on the consumers for this industry through a reduction in purchases (which may stem from uncertainty acting through the 'precautionary savings' channel). Resulting in the substantial decline in output, although it is difficult to draw a precise conclusion for this industry due to its broad nature.

Examining the Professional, Scientific and Technical Services industry, all three industry variables are shown to initially decline, rebound and overshoot in response to an economic uncertainty shock. Unlike output and employment, the decline in investment becomes briefly statistically significant in the second quarter, falling roughly 1.9 per cent. In contrast to employment and investment, when output overshoots, it becomes statistically significant in the third quarter, rising by a greater magnitude than observed by Mining output. The IRF of Professional, Scientific and Technical Services employment remains statistically insignificant; overall, the responses of all three industry measures are consistent with that of 
the 'real options' channel, due to the broad nature of this industry, it is difficult to draw important theoretical conclusions. ${ }^{26}$

Public Administration and Safety is shown to experience a decline in both output and employment, which soon after rebounds and overshoots, both responses are, however, statistically insignificant. This response may reflect the government nature of this industry, whereby employment contracts are likely to be relatively fixed; consequently, the industry does not have time to adjust employment decisions in response to an economic uncertainty shock.

Consistent results can be drawn from the Health Care and Social Assistance industry, as shown both output and employment experience immediate increases, followed by large declines which rebound and overshoot soon after. In terms of magnitude, the decline in output is more considerable than most other industries, peaking at approximately 0.3 per cent in the second quarter. Both responses become briefly statistically significant for one period. Due to the diverse nature of this industry, without sub-industries disaggregation, it is difficult to draw theoretical conclusions from the observed responses.

The results for the Mining industry somewhat contradict each other in comparison to other industries. Mining investment endures an immediate statistically significant negative decline, which soon after rebounds and overshoots (consistent with the 'real options' channel), however, in terms of magnitude, this response is relevantly small in comparison to a majority of the other industries. The subdued response of Mining investment may reflect the long-term investment nature of the industry, as Topp et al. (2008) outlines when capital investment occurs in the Mining industry, there is roughly a three year (12 quarter) lag until returns are realised. Meaning a temporary shock to economic uncertainty today may have little impact on Mining investment decisions since economic uncertainty levels will revert to normal by the time returns are realised. In contrast, Mining output and employment are shown to display positive, statistically significant responses to an economic uncertainty shock, which is generally

\footnotetext{
${ }^{26}$ Ideally, this problem would be overcome by analysing the sub-industries of Professional, Scientific and Technical Services; however, this is not possible due to the start date of the data series.
} 
inconsistent to the other industries. The next sub-section breaks the Mining industry into subindustries to see if a particular sub-industry is driving this unique response.

\subsection{Economic Uncertainty Shocks: Mining and Manufacturing sub-industries}

The sub-industries of Mining and Manufacturing are analysed to outline if the responses are unique and a potential driver of the overall industry. Refer to Figures A.1 and A.2, in Appendix D for the results.

The IRFs for the Mining sub-industries are mostly statistically insignificant, except for 'Oil and Gas Extraction', and 'Other Mining' which are briefly statistically significant in the fifth and fourth quarters, respectively. At their peaks, 'Oil and Gas Extraction' declines 0.5 per cent, whereas ‘Other Mining' increases by roughly 0.35 per cent. In terms of magnitude, 'Iron Ore Mining' and 'Exploration and Mining Support Services' experience declines up to 0.55 and 0.44 per cent at their respective peaks, each in the third quarter, however, both responses are statistically significant. The IRFs of 'Coal Mining' and 'Mining (Excluding Exploration and Mining Support Services)' are un-responsive. Immediate increases occur in five of the six Mining sub-industries, and in terms of magnitude, the largest immediate increase ( 0.54 per cent) occurs in 'Exploration and Mining Support Services', which may be a driver of the immediate increase observed for Mining output in Section 4.1.

With respect to the Manufacturing sub-industries, the response of 'Food, Beverage and Tobacco Products’ becomes briefly statistically significant in the third period and once again in the fourth period for one quarter, in terms of magnitude 'Food, Beverage and Tobacco Products' endures a peak decline of 0.32 per cent in the third quarter. 'Metal Products' experiences the largest decline of all the Manufacturing sub-industries of roughly 1.0 per cent in the third quarter, which is statistically significant. 'Petroleum, Coal, Chemical and Rubber Products' is shown to display an immediate (statistically significant) decline, peaking at 0.8 per cent in the second quarter, which soon after rebounds and overshoots. While, 'Machinery and 
Equipment' is shown to experience a decline of roughly 0.4 per cent at its peak in the fourth quarter, lastly, 'Other Manufacturing' is unresponsive and statistically insignificant.

\subsection{Variance Decompositions}

Table 1 outlines the variance decomposition results for the industry variable (either $I N V_{i t}, G V A_{i t}$, or $\left.E M P_{i t}\right)$ to an economic uncertainty shock in the Investment, Output and Employment Models. ${ }^{27}$

Economic uncertainty explains 10.32 and 6.00 per cent of the variation in Financial and Insurance Services investment and output after eight quarters, which is the most substantial in comparison to all other industries analysed. Additionally, economic uncertainty explains 1.90 per cent variation in employment after eight quarters. ${ }^{28}$

In the Construction industry, economic uncertainty accounts for 4.30 and 2.06 per cent variation in investment and output, which is comparable to the variation (3.96 and 2.63 per cent) in Manufacturing investment and output. In contrast, economic uncertainty accounts for 3.40 per cent variation in Construction employment, compared to only 1.32 per cent in Manufacturing employment.

In terms of employment, economic uncertainty explains the largest variation (4.53 per cent) in the Health Care and Social Assistance industry and accounts for a substantial level of variation (3.64 per cent) in Health Care and Social Assistance output. In contrast, economic uncertainty contributes only 1.40 and 1.85 per cent variation in Public Administration and Safety output and employment.

The effect of economic uncertainty accounts for only 1.18 and 1.90 per cent in Professional, Scientific and Technical Services employment and investment, in comparison to

\footnotetext{
${ }^{27}$ Please contact the authors is you require the variance decomposition results of each industry variable to shocks in all other variables.

${ }^{28}$ For the remaining paragraphs, to eliminate repetitiveness, each percentage of variation discussed in the text refers to variation after eight quarters, as can be seen in Table 2. Note that after eight periods, variation in the industry variable is similar for all future quarters.
} 
3.66 per cent variation in output. Lastly, economic uncertainty explains 2.71, 1.98 and 2.73 per cent variation in Mining investment, output and employment.

\subsection{Economic Uncertainty Shocks: Australian macroeconomic variables}

To analyse the impact of economic uncertainty on Australian macroeconomic variables, the three models are used to generate the IRF for all other variables to a one standard deviation impulse to economic uncertainty, see Figures A.3, to A.5, in Appendix D for the results. ${ }^{29}$

Domestic output experiences a sustained decline, which is consistent across all three models, and in the case of the Investment Model (Figure A.4, in Appendix D), the response of domestic output becomes statistically significant at its peak in the seventh period. Additionally, when examining the Investment Model, total investment is shown to experience an immediate decline, peaking in the fourth quarter (this response is statistically significant between quarters four to seven). ${ }^{30}$

In contrast, Figure A.5, in Appendix D, shows that total employment immediately increases (which is statistically significant for one quarter) and soon after falls below the baseline of zero, overall this response is unexpected. Additionally, Australian inflation endures a decline across all three models and becomes statistically significant between quarters four to 11. Likewise, the domestic interest rate displays a similar response and peaks in the third period; however, this response is only statistically significant in the Output and Employment Models, which lasts one quarter. Finally, the exchange rate undergoes a positive response to an economic uncertainty shock across all three models.

\footnotetext{
${ }^{29}$ In this instance, each of the three models excludes the industry variable, i.e. $G V A_{i t}, I N V_{i t}$ and $E M P_{i t}$.

${ }^{30}$ The responses of both domestic output and total investment are generally consistent with the empirical evidence discussed in Section 2.
} 


\section{ROBUSTNESS ANALYSIS}

SVARs are known to be sensitive to their specification; consequently, this section examines numerous specifications and alternative variables/proxies to ensure the results are robust. Refer to Figures A.6 to A.8, in Appendix E for the results. ${ }^{31}$

\subsection{Lag Length}

To determine whether the results are robust to an alternative lag length, the Output, Investment and Employment Models are estimated using two lags, rather than three. Two lags are chosen as the alternative due to being a frequent selection amongst Australian SVAR studies, and being a common recommendation of the AIC and HQ tests. ${ }^{32}$ Generally, the direction and magnitude are similar between the different lag specifications. Exceptions to this statement are Construction investment, which does not overshoot using two lags, and Mining output, which experiences a statistically significant negative decline in the third quarter. Additionally, when using two lags, Construction output immediately increases, and experiences a smaller decline in later periods, Public Administration and Safety output initially becomes statistically significant, Professional, Scientific and Technical Services investment and Manufacturing employment becomes statistically insignificant.

\subsection{Alternative Variable Specification}

In this section, we explore additional and alternate variables/proxies, refer to Table A.3, in Appendix B for a detailed description of the alternate variables/proxies.

\subsubsection{Alternative Variables}

Table 2 outlines alternative variables/proxies which are considered in place of the existing variables, and are substituted into each model one at a time. ${ }^{33}$

\footnotetext{
${ }^{31}$ The results for each industry are divided into two separate graphs; this is to allow greater readability since the impulse responses are less clustered.

32 Australian SVAR studies which use two lags include: Claus, Dungey \& Fry, (2008), Jacobs \& Rayner (2012), Dungey, Fry-McKibbin \& Linehan, (2014), Knop \& Vespignani (2014), Manalo, Perera \& Rees, (2015) and Dungey et al. (2017).

33 The exception of this is the global headline inflation, short-term policy rate and real GDP, which are substituted together.
} 
The measures for the global headline inflation, the short-term policy rate and real GDP are from the Database of Global Economic Indicators (DGEI) (Grossman, Mack \& MartínezGarcia, 2014). Although the DGEI are designed for researching the impact of the global economy on the U.S, they are tested to see their suitability in accounting for global economic conditions for Australia.

The results are similar in terms of magnitude and direction in comparison to the original three models. The main exception being the addition of the DGEI, which are shown to produce varying magnitudes of the IRFs compared to the three original models; however, the direction of the responses are generally consistent.

\subsubsection{Additional Variables}

Baker, Bloom \& Davis, (2016) and Cerda, Silva \& Valente, (2018) discuss the endogeneity concerns between measures of uncertainty and (consumer) confidence. To address the problem, they each introduce a measure of consumer confidence as an endogenous variable in their model. To be parsimonious, a measure of consumer confidence was not included in the original Models; however, it is here in the robustness analysis, and the ordering follows both Baker, Bloom \& Davis, (2016) and Cerda, Silva \& Valente, (2018), whereby, consumer confidence $\left(C O N S U_{t}\right)$ precedes $U N C E R_{t}$ and contemporaneously impacts all other domestic block variables. Additionally, two dummy variables are introduced into each model to account for structural changes in the Australian economy, firstly to capture the adjustment of the RBA to inflation-targeting, and secondly to account for the volatility of the global financial crisis. ${ }^{34}$

The addition of consumer confidence alters the magnitude of some responses; although, the difference is generally small, and the direction of the responses are relatively consistent with the original models.

\footnotetext{
34 The inflation targeting dummy variable is equal to 1 during the inflation-targeting period from 1993:1 to current and 0 otherwise, which is consistent with Jääskelä \& Smith (2013), Finlay \& Jääskelä (2014) and Manalo, Perera \& Rees, (2015). Whereas, the global financial crisis dummy variable is equal to 1 during 2008:4 to 2009:3 and 0 otherwise, consistent with Manalo, Perera \& Rees, (2015).
} 


\subsection{Variable Ordering and Contemporaneous Restrictions}

\subsubsection{Order of Economic Uncertainty}

Following Bloom (2009) in his robustness analysis, the economic uncertainty index is ordered last, meaning it is contemporaneously impacted by every other domestic block variable in the system, as shown in Equations 7 to 9 below. Similar to the findings of Moore (2017), ordering economic uncertainty last subdues the IRF; however, the difference is generally small, and the direction is mostly consistent in comparison to the original models. With the main exception of Professional, Scientific and Technical Services investment, which is shown to display a large statistically significant increase.

$$
\begin{aligned}
B_{0} X_{t} & =\left[\begin{array}{cccccc}
1 & 0 & 0 & 0 & 0 & 0 \\
b_{21} & 0 & 0 & 0 & 0 & 0 \\
b_{31} & b_{32} & 1 & 0 & 0 & 0 \\
b_{41} & 0 & b_{43} & 1 & 0 & 0 \\
b_{51} & b_{52} & b_{53} & b_{54} & 1 & 0 \\
b_{61} & b_{62} & b_{63} & b_{64} & b_{65} & 1
\end{array}\right] *\left[\begin{array}{c}
\Delta \log \left(A G D P_{-i t}\right) \\
\Delta \log \left(G V A_{i t}\right) \\
I N F_{t} \\
I N T_{t} \\
\Delta \log \left(T W I_{t}\right) \\
U N C E R_{t}
\end{array}\right] \\
B_{0} X_{t} & =\left[\begin{array}{ccccccc}
1 & 0 & 0 & 0 & 0 & 0 & 0 \\
b_{21} & 0 & 0 & 0 & 0 & 0 & 0 \\
b_{31} & b_{32} & 1 & 0 & 0 & 0 & 0 \\
b_{41} & b_{42} & b_{43} & 1 & 0 & 0 & 0 \\
b_{51} & b_{52} & 0 & b_{54} & 1 & 0 & 0 \\
b_{61} & b_{62} & b_{63} & b_{64} & b_{65} & 1 & 0 \\
b_{71} & b_{72} & b_{73} & b_{74} & b_{75} & b_{76} & 1
\end{array}\right] *\left[\begin{array}{c}
\Delta \log \left(A G D P_{t}\right) \\
\log \left(I N V_{-i t}\right) \\
\Delta \log \left(I N V_{i t}\right) \\
I N F_{t} \\
I N T_{t} \\
\Delta \log \left(T W I_{t}\right) \\
U N C E R_{t}
\end{array}\right] \\
B_{0} X_{t} & =\left[\begin{array}{ccccccc}
1 & 0 & 0 & 0 & 0 & 0 & 0 \\
b_{21} & 0 & 0 & 0 & 0 & 0 & 0 \\
b_{31} & b_{32} & 1 & 0 & 0 & 0 & 0 \\
b_{41} & b_{42} & b_{43} & 1 & 0 & 0 & 0 \\
b_{51} & b_{52} & 0 & b_{54} & 1 & 0 & 0 \\
b_{61} & b_{62} & b_{63} & b_{64} & b_{65} & 1 & 0 \\
b_{71} & b_{72} & b_{73} & b_{74} & b_{75} & b_{76} & 1
\end{array}\right] *\left[\begin{array}{c}
\Delta \log \left(A G D P_{t}\right) \\
\Delta \log \left(E M P_{-i t}\right) \\
\Delta \log \left(E M P_{i t}\right) \\
I N F_{t} \\
I N T_{t} \\
\Delta \log \left(T W I_{t}\right) \\
U N C E R_{t}
\end{array}\right]
\end{aligned}
$$

\subsubsection{Ordering of the Investment and Employment Models}

Alternate variable orderings are used to highlight that the results are consistent regardless of the ordering scheme; alternating the ordering follows Bloom (2009) and ensures consistent results are drawn. To consider a broad range of alternatives, both the investment and employment variables in each of their respective models are ordered prior to $A G D P_{t}$ (after 
$U N C E R_{t}$ ), and also after $I N F_{t}$ (prior to $T W I_{t}$ ). For simplicity, the Cholesky decomposition is applied to both of the alternative ordering schemes.

The alternative orderings have no impact on the IRFs; therefore, we can conclude that regardless of the ordering scheme, consistent empirical results can be drawn.

\subsubsection{Alternative Contemporaneous Restrictions}

As an alternative, the standard lower triangular (Cholesky Decomposition) recursive identification scheme is evaluated for the Output, Investment and Employment Models; when applied, there are no observable changes to the IRFs.

\section{CONCLUSION}

This is the first study to present empirical evidence of the impact of economic uncertainty shocks on industrial: investment, output and employment, in Australia. Overall, the Construction and Financial and Insurance Services industries are the most impacted by an economic uncertainty shock. In contrast, Public Administration and Safety is the least impacted.

The Construction industry experiences statistically significant declines of up to 3.6, 0.4 and 0.37 per cent across investment, output and employment in response to an economic uncertainty shock, and in terms of magnitude the declines in output and employment are the largest across all industries. The sensitive nature of the Construction industry may be linked to its reliance on financing when undertaking investment projects through the 'risk premia' channel of uncertainty. Additionally, in terms of variance decomposition economic uncertainty explains 4.27 and 3.44 per cent variation in Construction investment and employment after eight quarters, which is considerable in comparison to other industries.

The Financial and Insurance Services industry endures the most substantial decline in investment, which peaks at 4.2 per cent in the second quarter and is statistically significant for one period. This large negative response may reflect the ability of the Financial and Insurance Services industry to readily respond to news, and other related economic uncertainty events, which causes firms to re-access their investment activates in a much faster time frame in 
comparison to other industries. Furthermore, Financial and Insurance Services output is shown to decline approximately 0.24 per cent in response to an economic uncertainty shock, whereas, employment is shown to immediately decrease before overshooting in the second quarter. In terms of variance decomposition, economic uncertainty contributes 10.30 and 5.95 per cent variation after eight quarters in Financial and Insurance Services investment and output, which is the most substantial amount compared to all other industries. In contrast, economic uncertainty only accounts for 1.90 per cent in Financial and Insurance Services employment.

Public Administration and Safety output and employment are statistically insignificant, and economic uncertainty only explains 1.41 and 1.85 per cent variation in each output and employment after eight quarters. This response may reflect the government nature of this industry, whereby employment is relatively more fixed and the industry as a whole is unable to readily adjust employment decisions in response to an economic uncertainty shock.

Furthermore, disaggregating the Mining and Manufacturing industries, the 'Petroleum, Coal, Chemical and Rubber Products', 'Metal Products', and 'Iron Ore Mining' sub-industries endure the most substantial declines. Additionally, at an aggregate level, economic uncertainty shocks are shown to depress both Australian output and investment.

A possible extension of this research may include expanding the analysis to account for the stylised fact that uncertainty increases during a recession, isolating the response during recessionary periods. The results of this paper emphasise that individual industries have unique responses to an economic uncertainty shock and do not necessarily reflect the response of the broader aggregate macroeconomy. Highlighting how it is crucial to understand the relationship between economic uncertainty and the macroeconomy at a disaggregated level. The empirical findings in this study will help guide public policy evaluation for industries, as well as private and public investment decisions in Australia. 


\section{REFERENCES}

Baker, SR, Bloom, N \& Davis, SJ 2016, 'Measuring economic policy uncertainty', The Quarterly Journal of Economics, vol. 131, no. 4, pp. 1593-636.

Berkelmans, L 2005, 'Credit and monetary policy: an Australian SVAR', Reserve Bank of Australia, Research Discussion Paper 2005-06.

Bernanke, BS 1983, 'Irreversibility, uncertainty, and cyclical investment', The Quarterly Journal of Economics, vol. 89, no. 1, pp. 85-106.

Bloom, N 2009, ‘The impact of uncertainty shocks’, Econometrica, vol. 77, no. 3, pp. 623-85.

Bloom, N 2014, ‘Fluctuations in uncertainty', Journal of Economic Perspectives, vol. 28, no. 2, pp. 153-76.

Caggiano, G, Castelnuovo, E \& Groshenny, N 2014, 'Uncertainty shocks and unemployment dynamics in U.S. recessions', Journal of Monetary Economics, vol. 67, pp. 78-92.

Caggiano, G, Castelnuovo, E \& Nodari, G 2017, 'Uncertainty and monetary policy in good and bad times', Melbourne Institute of Applied Economic and Social Research, Research Discussion Paper No. 9/17.

Caggiano, G, Castelnuovo, E \& Pellegrino, G 2017, 'Estimating the real effects of uncertainty shocks at the zero lower bound', European Economic Review, vol. 100, pp. 257-72.

Carrière-Swallow, Y \& Céspedes, LF 2013, 'The impact of uncertainty shocks in emerging economies’, Journal of International Economics, vol. 90, pp. 316-25.

Cerda, R, Silva, A \& Valente, JT 2018, 'Impact of economic uncertainty in a small open economy: the case of Chile’, Applied Economics, vol. 50, no. 26, pp. 2894-908.

Chung, E, Kohler, M \& Lewis, C 2011, 'The exchange rate and consumer prices’, Reserve Bank of Australia Bulletin, September Quarter, pp. 9-16.

Claus, E, Dungey, M \& Fry, R 2008, 'Monetary policy in illiquid markets: options for a small open economy’, Open Economies Review, vol. 19, no. 3, pp. 305-36.

Denis, S \& Kannan, P 2013, 'The impact of uncertainty shocks on the UK economy', International Monetary Fund, Working Paper/13/66.

Dungey, M \& Pagan, A 2000, 'A structural VAR model of the Australian economy', Economic Record, vol. 76, no. 235, pp. 321-42.

Dungey, M \& Pagan, A 2009, 'Extending a SAVR model of the Australian economy', Economic Record, vol. 85, no. 268, pp. 1-20.

Dungey, M, Fry-McKibbin, R \& Linehan, V 2014, 'Chinese resource demand and the natural resource supplier’, Applied Economics, vol. 46, no. 2, pp. 167-78.

Dungey, M, Fry-McKibbin, R, Todoroski, V \& Volkov, V 2017, 'Recovery from Dutch Disease’, Centre for Applied Macroeconomic Analysis, Working Paper 69/2017. 
Finlay, R \& Jääskelä, JP 2014, 'Credit supply shocks and the global financial crisis in three small open economies’, Journal of Macroeconomics, vol. 40, pp. 270-76.

Fry, R \& Pagan, A 2011, 'Sign restrictions in structural vector autoregressions: a critical review’, Journal of Economic Literature, vol. 49, no. 4, pp. 938-60.

Gieseck, A \& Largent, Y 2016, 'The impact of macroeconomic uncertainty on activity in the Euro Area’, Review of Economics, vol. 67, no. 1, pp. 25-52.

Girardi, A \& Reuter, A 2017, 'New uncertainty measures for the Euro Area using Survey data', Oxford Economic Papers, vol. 69, no. 1, pp. 278-300.

Grossman, V, Mack, A \& Martínez-García, E 2014, 'A new database of global economic indicators', Journal of Economic and Social Measurement, vol. 39, pp. 163-97.

Gulen, H \& Ion, M 2016, 'Policy uncertainty and corporate investment', Review of Financial Studies, vol. 29, no. 3, pp. 523-64.

Hu, Z, Kutan, AM \& Sun, P 2018, 'Is U.S. economic policy uncertainty prices in China's Ashares market? Evidence from market, industry, and individual stocks’, International Review of Financial Analysis, vol. 57, pp. 207-20.

Istiak, K \& Serletis, A 2018, 'Economic policy uncertainty and real output: evidence from the G7 countries’, Applied Economics, vol. 50, no. 39, pp. 4222-33.

Jääskelä, JP \& Jennings, D 2011, 'Monetary policy and the exchange rate: evaluation of VAR models’, Journal of International Money and Finance, vol. 30, no. 7, pp. 1358-74.

Jääskelä, JP \& Smith, P 2013, 'Terms of trade shocks: what are they and what do they do?', Economic Record, vol. 89, no. 285, pp. 145-59.

Jacobs, D \& Rayner, V 2012, 'The role of credit supply in the Australian economy', Reserve Bank of Australia, Research Discussion Paper 2012-02.

Kang, W, Lee, K \& Ratti, RA 2014, 'Economic policy uncertainty and firm-level investment', Journal of Macroeconomics, vol. 39, pp. 42-53.

Knop, SJ 2013, 'The sectoral impact of commodity price shocks in Australia', BEc(Hons) Thesis, University of Tasmania.

Knop, SJ \& Vespignani, JL 2014, 'The sectorial impact of commodity price shocks in Australia’, Economic Modelling, vol. 42, pp. 257-71.

Lawson, J \& Rees, D 2008, 'A sectoral model of the Australian economy', Reserve Bank of Australia, Research Discussion Paper 2008-01.

Liu, P 2010, 'The effects of international shocks on Australia's business cycle', Economic Record, vol. 86, no. 275, pp. 486-503.

Manalo, J, Perera, D \& Rees, DM 2015, 'Exchange rate movements and the Australian economy', Economic Modelling, vol. 47, pp. 53-62. 
Meinen, P \& Roehe, O 2017, 'On measuring uncertainty and its impact on investment: crosscountry evidence from the Euro Area’, European Economic Review, vol. 92, pp. 161-79.

Moore, A 2017, 'Measuring economic uncertainty and its effects', Economic Record, vol. 93, no. 303, pp. 550-75.

Phan, DHB, Sharma, SS \& Tran, VT 2018, 'Can economic policy uncertainty predict stock returns? Global evidence', Journal of International Financial Markets, Institutions \& Money, vol. 55, pp. 134-50.

Sorić, P \& Lolić, I 2017, 'Economic uncertainty and its impact on the Croatian economy', Public Sector Economics, vol. 41, no. 4, pp. 443-77.

Topp, V, Soames, L, Parham, D \& Bloch, H 2008, 'Productivity in the mining industry: measurement and interpretation', Productivity Commission, Staff Working Paper.

Tran, TL 2014, 'Uncertainty and investment: evidence from Australian firm panel data', Economic Record, vol. 90, pp. 87-101.

Vespignani, JL 2013, 'The industrial impact of monetary shocks during the inflation-targeting era in Australia’, Australian Economic History Review, vol. 53, no. 1, pp. 47-71.

Vespignani, JL 2015, 'On the differential impact of monetary policy across states/territories and its determinants in Australia: Evidence and new methodology from a small open economy', Journal of International Financial Markets, Institutions and Money, vol. 34, pp. 1-13. 
Table 1

Variance decomposition of all industries to an economic uncertainty shock, in per cent

Proportion of forecast error variance

\begin{tabular}{lcccccc} 
& \multicolumn{2}{c}{ Investment } & \multicolumn{2}{c}{ Output } & \multicolumn{2}{c}{ Employment } \\
\cline { 2 - 7 } Quarter & 4 & 8 & 4 & 8 & 4 & 8 \\
\hline Mining & 2.59 & 2.71 & 2.02 & 1.98 & 2.48 & 2.73 \\
Manufacturing & 2.61 & 3.96 & 2.39 & 2.63 & 1.17 & 1.32 \\
Construction & 4.03 & 4.30 & 1.73 & 2.06 & 3.13 & 3.40 \\
Financial & 10.58 & 10.32 & 5.05 & 6.00 & 1.70 & 1.90 \\
Professional & 1.87 & 1.90 & 3.74 & 3.66 & 1.13 & 1.18 \\
Public Administration & & & 1.20 & 1.40 & 1.65 & 1.85 \\
Health Care & & & 3.63 & 3.64 & 4.59 & 4.53 \\
\hline
\end{tabular}

Table 2

Alternative variables to be used in the industrial models

\begin{tabular}{ll}
\hline Variables in the original three models & Alternative variables to be considered \\
\hline $\begin{array}{l}\text { Trade-weighted world economic variables } \\
\text { (inflation and interest rates) }\end{array}$ & Global headline inflation and short-term policy rate \\
Major trade partner real GDP & Global real GDP \\
Real Australian non-farm GDP & Total real Australian GDP \\
Trimmed mean inflation rate & Weighted-median inflation rate \\
\hline Note these variables/proxies are substituted into the output, investment and employment Models outlined in \\
$\begin{array}{ll}\text { Equations } 1 \text { to 3, and follow the same contemporaneous interactions set out in Equations } 4 \text { to } 6 \text { unless otherwise } \\
\text { stated. }\end{array}$
\end{tabular}


Figure 1

Australian index of economic uncertainty (monthly frequency)

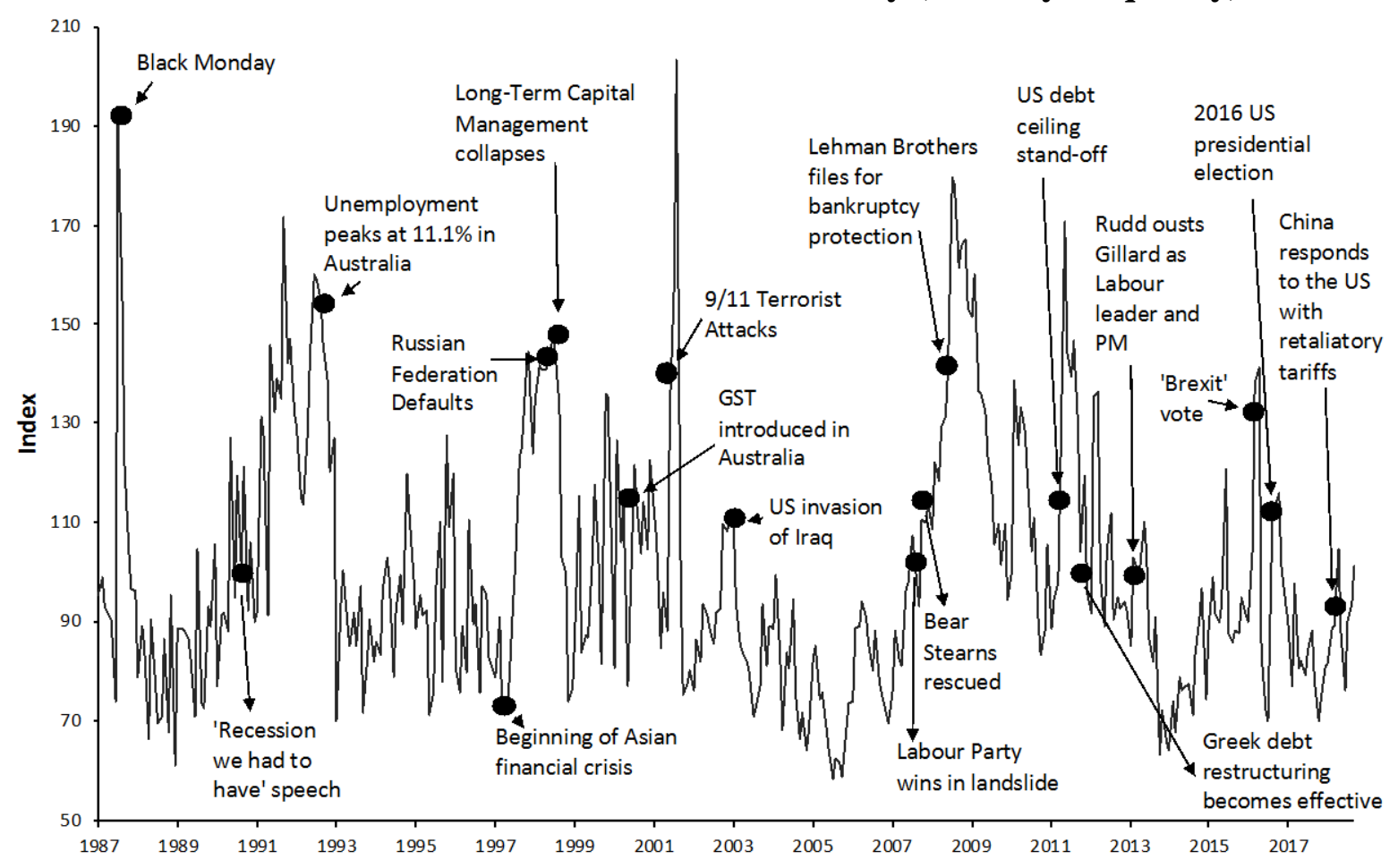

Sources: Moore (2017), Thomson Reuters and policyuncertainty.com.

Figure 2

Australia's largest trading partners in terms of total trade value

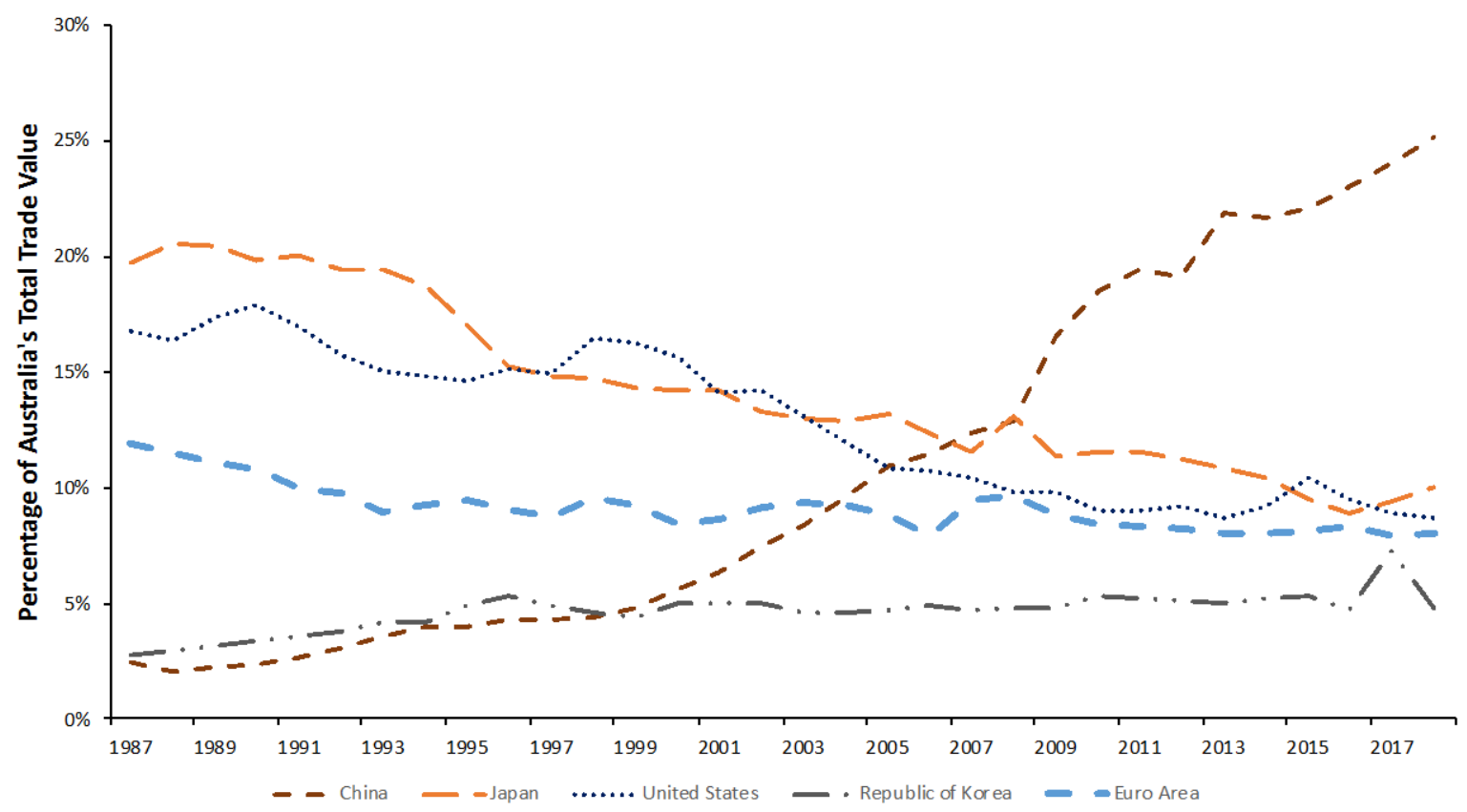

Source: Department of Foreign Affairs and Trade, Trade Statistics, Trade time series data, Direction of goods and services trade. 
Figure 3

Impulse response functions of all industries, to a one standard deviation shock to economic uncertainty
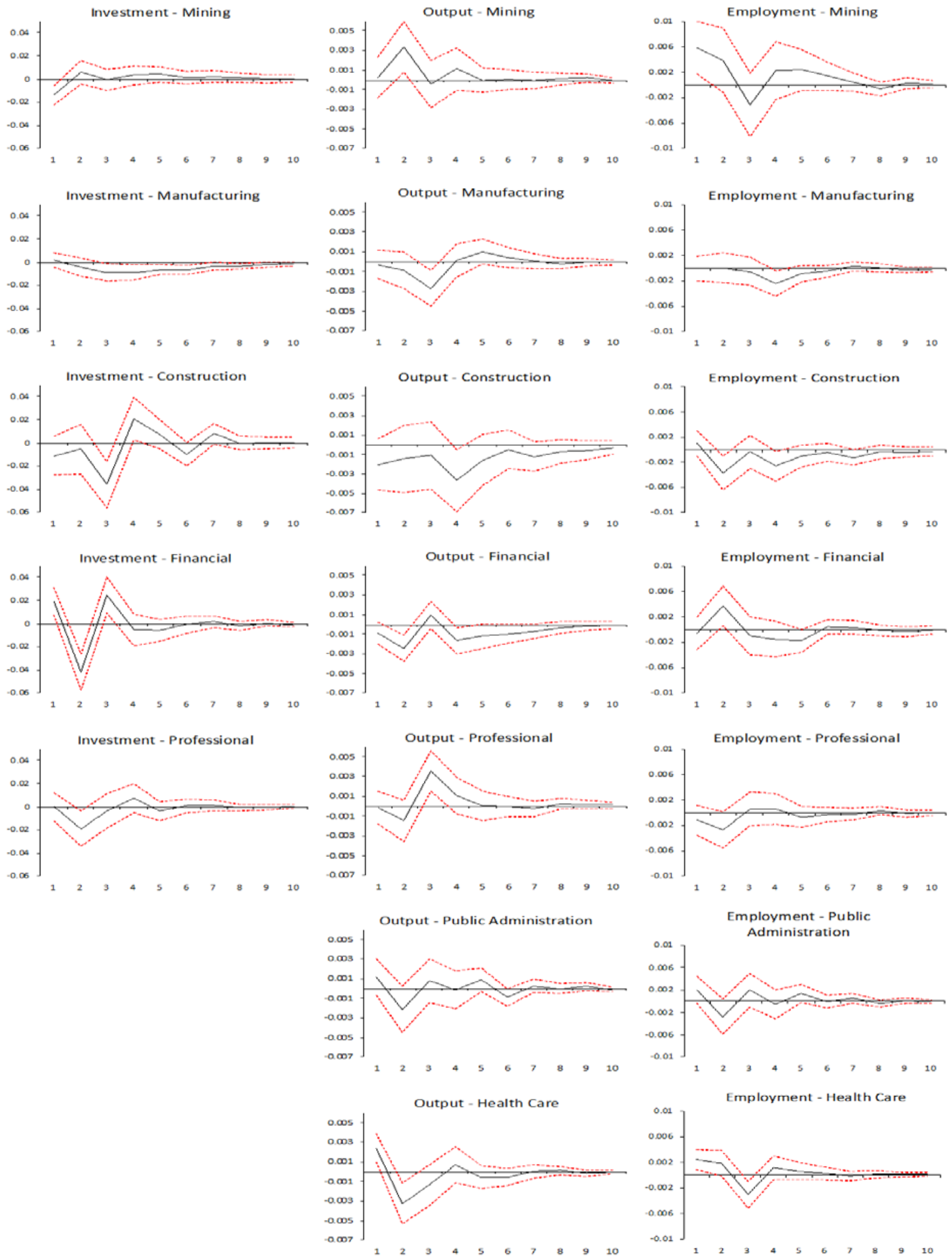

The solid black line represents the impulse response, and the dashed red lines represent the asymptotic standard error, in this study, one standard error is used. The vertical axis shows the percentage change, whereas, the horizontal axis shows the periods (quarters). 


\section{APPENDIX A: LITERATURE REVIEW SUMMARY}

Table A.1

Summary of literature

\begin{tabular}{|c|c|c|c|c|}
\hline Author(s) & $\begin{array}{l}\text { Measure of } \\
\text { uncertainty }\end{array}$ & $\begin{array}{l}\text { Countries } \\
\text { Analysed }\end{array}$ & Methodology & Data Period \\
\hline Bloom (2009) & $\begin{array}{l}\text { Uncertainty dummy } \\
\text { based on the VXO }\end{array}$ & United States & $\begin{array}{l}\text { VAR and a model } \\
\text { with a time-varying } \\
\text { second moment }\end{array}$ & $\begin{array}{l}\text { June } 1962 \text { to June } \\
2008\end{array}$ \\
\hline $\begin{array}{l}\text { Sorić \& Lolić } \\
(2017)\end{array}$ & Several measures * & Croatia & $\begin{array}{l}\text { SVAR (fixed and } \\
\text { timing-varying } \\
\text { parameters) }\end{array}$ & $\begin{array}{l}\text { November } 2002 \text { to } \\
\text { December } 2016\end{array}$ \\
\hline $\begin{array}{l}\text { Carrière-Swallow } \\
\text { \& Céspedes } \\
\text { (2013) }\end{array}$ & VXO index & $\begin{array}{l}\text { Developed and } \\
\text { developing } \\
\text { Countries } * *\end{array}$ & Open-economy VAR & $\begin{array}{l}\text { March } 1990 \text { to } \\
\text { March } 2011\end{array}$ \\
\hline $\begin{array}{l}\text { Kang, Lee \& } \\
\text { Ratti, (2014) }\end{array}$ & $\begin{array}{l}\text { Economic policy } \\
\text { uncertainty }\end{array}$ & United States & $\begin{array}{l}\text { Error correction } \\
\text { model of capital } \\
\text { stock adjustment }\end{array}$ & $\begin{array}{l}\text { January } 1985 \text { to } \\
\text { December } 2010\end{array}$ \\
\hline $\begin{array}{l}\text { Gulen \& Ion } \\
\text { (2016) }\end{array}$ & $\begin{array}{l}\text { Economic policy } \\
\text { uncertainty }\end{array}$ & United States & $\begin{array}{l}\text { Investment model } \\
\text { and VAR }\end{array}$ & $\begin{array}{l}\text { January } 1987 \text { to } \\
\text { December } 2013\end{array}$ \\
\hline $\begin{array}{l}\text { Meinen \& Roehe } \\
\text { (2017) }\end{array}$ & $\begin{array}{l}\text { Five measures of } \\
\text { uncertainty \# }\end{array}$ & $\begin{array}{l}\text { Germany, } \\
\text { France, Italy } \\
\text { and Spain }\end{array}$ & $\begin{array}{l}\text { Descriptive and } \\
\text { SVAR analysis }\end{array}$ & $\begin{array}{l}\text { July } 1996 \text { to } \\
\text { December } 2012\end{array}$ \\
\hline Tran (2014) & Several measures \#\# & Australia & Investment model & 1987 to 2009 \\
\hline $\begin{array}{l}\text { Denis \& Kannan } \\
\text { (2013) }\end{array}$ & $\begin{array}{l}\text { Stock volatility and } \\
\text { forecast dispersion }\end{array}$ & $\begin{array}{l}\text { United } \\
\text { Kingdom }\end{array}$ & VAR & $\begin{array}{l}\text { June } 1984 \text { to } \\
\text { September } 2011\end{array}$ \\
\hline $\begin{array}{l}\text { Istiak \& Serletis } \\
\text { (2018) }\end{array}$ & $\begin{array}{l}\text { Economic policy } \\
\text { uncertainty }\end{array}$ & G7 countries & Non-linear SVAR & $\begin{array}{l}\text { January } 1985 \text { to } \\
\text { March } 2015\end{array}$ \\
\hline $\begin{array}{l}\text { Gieseck \& } \\
\text { Largent (2016) }\end{array}$ & Several measures $\wedge$ & Euro Area & Multivariate SVAR & $\begin{array}{l}\text { March } 1999 \text { to } \\
\text { December } 2015\end{array}$ \\
\hline $\begin{array}{l}\text { Caggiano, } \\
\text { Castelnuovo \& } \\
\text { Groshenny, } \\
\text { (2014) }\end{array}$ & VIX & United States & $\begin{array}{l}\text { Non-linear, Smooth } \\
\text { Transition VAR }\end{array}$ & $\begin{array}{l}\text { September } 1962 \text { to } \\
\text { September } 2012\end{array}$ \\
\hline $\begin{array}{l}\text { Baker, Bloom \& } \\
\text { Davis, (2016) }\end{array}$ & $\begin{array}{l}\text { Economic policy } \\
\text { uncertainty }\end{array}$ & $\begin{array}{l}\text { Various } \\
\text { countries } \wedge \wedge\end{array}$ & $\begin{array}{l}\text { Firm-level } \\
\text { regressions, VAR, } \\
\text { panel-VAR }\end{array}$ & $\begin{array}{l}\text { January } 1985 \text { to } \\
\text { December } 2014\end{array}$ \\
\hline $\begin{array}{l}\text { Caggiano, } \\
\text { Castelnuovo \& } \\
\text { Nodari, (2017) }\end{array}$ & $\begin{array}{l}\text { Uncertainty dummy } \\
\text { based on the VXO }\end{array}$ & United States & $\begin{array}{l}\text { Non-linear, Smooth } \\
\text { Transition VAR }\end{array}$ & $\begin{array}{l}\text { July } 1962 \text { to June } \\
2008\end{array}$ \\
\hline
\end{tabular}




\begin{tabular}{|c|c|c|c|c|}
\hline Author(s) & $\begin{array}{l}\text { Measure of } \\
\text { uncertainty }\end{array}$ & $\begin{array}{l}\text { Countries } \\
\text { Analysed }\end{array}$ & Methodology & Data Period \\
\hline $\begin{array}{l}\text { Girardi \& Reuter } \\
\text { (2017) }\end{array}$ & $\begin{array}{l}\text { Survey-based } \\
\text { measures }\end{array}$ & Euro Area & VAR & $\begin{array}{l}\text { March } 1999 \text { to } \\
\text { December } 2014\end{array}$ \\
\hline Moore (2017) & Board measure & Australia & VAR & $\begin{array}{l}\text { October } 1986 \text { to } \\
\text { December } 2014\end{array}$ \\
\hline $\begin{array}{l}\text { Cerda, Silva \& } \\
\text { Valente, (2018) }\end{array}$ & $\begin{array}{l}\text { News-based } \\
\text { uncertainty }\end{array}$ & Chile & VAR & $\begin{array}{l}\text { March } 1992 \text { to } \\
\text { December } 2015\end{array}$ \\
\hline $\begin{array}{l}\text { Phan, Sharma \& } \\
\text { Tran, (2018) }\end{array}$ & $\begin{array}{l}\text { Economic policy } \\
\text { uncertainty }\end{array}$ & $\begin{array}{l}\text { Large sample of } \\
\text { countries }^{\circ}\end{array}$ & $\begin{array}{l}\text { Feasible generalised } \\
\text { least squares } \\
\text { estimator }\end{array}$ & \\
\hline $\begin{array}{l}\text { Hu, Kutan \& } \\
\text { Sun, (2018) }\end{array}$ & $\begin{array}{l}\text { Economic policy } \\
\text { uncertainty }\end{array}$ & China & $\begin{array}{l}\operatorname{ARMA}(1,1) \text { and } \\
\operatorname{GARCH}(1,1)\end{array}$ & $\begin{array}{l}\text { March } 2006 \text { to } \\
\text { April } 2016\end{array}$ \\
\hline
\end{tabular}

* 5 media-based measures, 4 disagreement measures, and 1 composite measure of uncertainty.

** Developed countries: Australia, Austria, Canada, Denmark, Finland, France, Italy, Japan, Netherlands, New Zealand, Norway, Switzerland, United Kingdom, United States, Belgium, Israel, Germany, Russia, Spain and Sweden. Developing countries: Chile, Hong Kong, Mexico, Philippines, South Africa, South Korea, Turkey, Argentina, Brazil, Colombia, Croatia, Czech Republic, Estonia, Hungary, Indonesia, Malaysia, Peru, Poland, Portugal and Thailand.

\# Implied volatility of stock market returns, economic policy uncertainty, the cross-sectional dispersion of production expectations in business surveys, and the unpredictable components of a large set of macroeconomic indicators.

\#\# Volatility of returns of firms' stock prices, idiosyncratic (micro) uncertainty, and market (macro) uncertainty. $\wedge$ Systematic stress indicator, political uncertainty indicator, macroeconomic uncertainty indicator and financial market uncertainty indicator.

$\wedge \wedge$ United States, India, Canada, South Korea, France, Germany, Italy, Japan, Spain, United Kingdom, China and Russia.

○ Australia, Brazil, Canada, China, France, Germany, India, Ireland, Italy, Japan, South Korea, the Netherlands, Russia, Spain, the United Kingdom, and the United States. 


\section{APPENDIX B: DATA DESCRIPTION}

Table A.2

Data description, sources and transformations

\begin{tabular}{|c|c|}
\hline Variable & Description and Source \\
\hline$W G D P_{t}$ & $\begin{array}{l}\text { Real world GDP, } 2015 \text { \$US, constant prices } \\
\text { (Datastream codes: CHXGDP\$.C, JPXGDP\$.D, } \\
\text { USXGDP\$.D, EKXGDP\$.D, KOXGDP\$.D). }\end{array}$ \\
\hline$W_{I N F_{t}}$ & $\begin{array}{l}\text { World quarterly change in the consumer price } \\
\text { index (Datastream codes: CHXCPI.\%R, } \\
\text { JPXCPI.\%R, USXCPI.\%Q, EKXCPI.\%R, } \\
\text { KOXCPI.\%R). }\end{array}$ \\
\hline$W_{N} T_{t}$ & $\begin{array}{l}\text { World short-term official/policy rate (Datastrear } \\
\text { codes: CHXRCB..R, JPXRCB..R, USXRCB..R, } \\
\text { EKXRCB..R, KOXRCB..R). }\end{array}$ \\
\hline$A G D P_{t}$ & $\begin{array}{l}\text { Seasonally adjusted, chain volume measure of } \\
\text { non-farm GDP (RBA, Statistical Table, H1). }\end{array}$ \\
\hline$G V A_{i t}$ & $\begin{array}{l}\text { Seasonally adjusted, chain volume measure of } \\
\text { industry gross value added (ABS, Cat No. } \\
5206.0 \text { Table 6). }\end{array}$ \\
\hline$E M P_{i t}$ & $\begin{array}{l}\text { Employed persons by industry division of main } \\
\text { job, seasonally adjusted (ABS, Cat No. } \\
\text { 6291.0.55.003, Table } 4 \text { ). * }\end{array}$ \\
\hline INV $V_{i t}$ & $\begin{array}{l}\text { Private new capital expenditure, actual } \\
\text { expenditure, detailed industries, seasonally } \\
\text { adjusted, current prices (ABS, Cat No. 5625.0, } \\
\text { Table 2E). }\end{array}$ \\
\hline$I N T_{t}$ & $\begin{array}{l}\text { Australian cash rate target/interbank overnight } \\
\text { cash rate (RBA, Statistical Table, F1.1). }\end{array}$ \\
\hline$I N F_{t}$ & $\begin{array}{l}\text { Seasonally adjusted consumer price index; } \\
\text { Trimmed mean; Quarterly change (in per cent) } \\
\text { (RBA, Statistical Table, G1). }\end{array}$ \\
\hline
\end{tabular}

COM $\quad$ Australian index of commodity prices, all items, 2017/18 = 100, US\$ (RBA, Statistical Table, I2).

Deflated by the Australian consumer price index, all groups.

Converted from monthly to quarterly using a 3month average.

Converted from monthly to quarterly using a 3month average. Deflated by the US CPI for all Urban Consumers (FRED).

TOT $_{\boldsymbol{t}}$ Seasonally adjusted Australian terms of trade index (ABS, Cat No. 5206.0 Table 1).

TWI $_{\boldsymbol{t}}$ Real Australian dollar trade-weighted exchange rate index, adjusted for relative consumer price levels, March 1995 = 100 (RBA, Statistical Table, F15).

UNCER $\boldsymbol{R}_{\boldsymbol{t}}$ Australian economic uncertainty index (RBA, research discussion paper 2016-01

Converted from monthly to quarterly using a 3month average.

\footnotetext{
* The observations are collected in the second month of the collection period, compared to the third month, as with all other quarterly data in this study. It is assumed that this month difference has no impact on the, data and it is treated as if it was collected in the third month.
} 
Table A.3

Data description, sources and transformations (robustness analysis variables)

\begin{tabular}{|c|c|c|}
\hline Variable & Description and Source & Transformations \\
\hline$W_{W D P_{t}}$ & $\begin{array}{l}\text { Seasonally adjusted, real GDP (Database of } \\
\text { Global Economic Indicators). }\end{array}$ & $\begin{array}{l}\text { To include the U.S economy, a weighted } \\
\text { average using the U.S share of the world } \\
\text { economy was employed (based on the shares } \\
\text { of the world economy from the International } \\
\text { Monetary Fund). }\end{array}$ \\
\hline$W_{N} F_{t}$ & $\begin{array}{l}\text { Seasonally adjusted, headline inflation } \\
\text { (Database of Global Economic Indicators). }\end{array}$ & $\begin{array}{l}\text { To include the U.S economy, a weighted } \\
\text { average using the U.S share of the world } \\
\text { economy was employed (based on the shares } \\
\text { of the world economy from the International }\end{array}$ \\
\hline$W I N T_{t}$ & $\begin{array}{l}\text { Seasonally adjusted, short-term official/policy } \\
\text { rate (Database of Global Economic Indicators). }\end{array}$ & $\begin{array}{l}\text { Monetary Fund). Additionally, the data was } \\
\text { converted from monthly to quarterly using a } 3- \\
\text { month average. }\end{array}$ \\
\hline$A G D P_{t}$ & $\begin{array}{l}\text { Seasonally adjusted, chain volume measure of } \\
\text { gross domestic product, (ABS, Cat No. 5606.0, } \\
\text { Table 6). }\end{array}$ & \\
\hline$I N F_{t}$ & $\begin{array}{l}\text { Seasonally adjusted consumer price index; } \\
\text { Weighted median; Quarterly change (in per } \\
\text { cent), (RBA, Statistical Table, G1). }\end{array}$ & \\
\hline $\mathrm{CONSU}_{t}$ & $\begin{array}{l}\text { ANZ Roy-Morgan Australian consumer } \\
\text { confidence index (Roy Morgan, Morgan Poll). }\end{array}$ & $\begin{array}{l}\text { Converted from monthly to quarterly using a } \\
\text { 3-month average. }\end{array}$ \\
\hline$D U M \_I N F_{t}$ & $\begin{array}{l}\text { Equal to } 1 \text { during the inflation-targeting period } \\
\text { from 1993:1 to current and } 0 \text { otherwise. }\end{array}$ & \\
\hline$D U M \_G F C t$ & $\begin{array}{l}\text { Equal to } 1 \text { during } 2008: 4 \text { to } 2009: 3 \text { and } 0 \\
\text { otherwise. }\end{array}$ & \\
\hline
\end{tabular}




\section{APPENDIX C: TESTS FOR MODEL SUITABILITY}

Table A.4

Log-ratio tests for over-parameterisation

\begin{tabular}{|c|c|c|}
\hline Model & Industry/Sub-Industry & Chi-Square (1) \\
\hline \multirow[t]{5}{*}{ Investment } & Mining & $2.17(0.14)$ \\
\hline & Manufacturing & $0.68(0.41)$ \\
\hline & Construction & $1.12(0.29)$ \\
\hline & Financial and Insurance Services & $3.60(0.06)$ \\
\hline & Professional, Scientific and Technical Services & $0.90(0.34)$ \\
\hline \multirow[t]{18}{*}{ Output } & Mining & $0.06(0.81)$ \\
\hline & Manufacturing & $4.85(0.03)$ \\
\hline & Construction & $1.74(0.19)$ \\
\hline & Financial and Insurance Services & $15.76(0.00)$ \\
\hline & Professional, Scientific and Technical Services & $1.15(0.28)$ \\
\hline & Public Administration and Safety & $1.37(0.24)$ \\
\hline & Health Care and Social Assistance & $2.78(0.10)$ \\
\hline & Coal Mining & $0.28(0.60)$ \\
\hline & Oil and Gas Extraction & $2.27(0.13)$ \\
\hline & Iron Ore Mining & $13.46(0.00)$ \\
\hline & Other Mining & $1.85(0.17)$ \\
\hline & Mining (Excluding Exploration and Mining Support Services) & $0.00(0.95)$ \\
\hline & Exploration and Mining Support Services & $0.38(0.54)$ \\
\hline & Food, Beverage and Tobacco Products & $2.49(0.11)$ \\
\hline & Petroleum, Coal, Chemical and Rubber Products & $3.74(0.05)$ \\
\hline & Metal Products & $1.15(0.28)$ \\
\hline & Machinery and Equipment & $7.23(0.01)$ \\
\hline & Other Manufacturing & $0.95(0.33)$ \\
\hline \multirow[t]{7}{*}{ Employment } & Mining & $3.21(0.07)$ \\
\hline & Manufacturing & $5.29(0.02)$ \\
\hline & Construction & $1.56(0.21)$ \\
\hline & Financial and Insurance Services & $0.87(0.35)$ \\
\hline & Professional, Scientific and Technical Services & $0.26(0.61)$ \\
\hline & Public Administration and Safety & $0.14(0.71)$ \\
\hline & Health Care and Social Assistance & $0.69(0.41)$ \\
\hline
\end{tabular}

The null hypothesis is that the over-identification restrictions are valid. The test-statistics are shown in the righthand side column, while the p-values are reported in the parenthesises. 
Table A.5

Stationarity test tesults

\begin{tabular}{|c|c|c|c|c|c|}
\hline Variable & ADF & KPSS & Variable & ADF & KPSS \\
\hline $\log \left(W G D P_{t}\right)$ & -1.15 & $3.27 * * *$ & $\Delta \log \left(W G D P_{t}\right)$ & $-3.28 * *$ & 0.12 \\
\hline$W I N T_{t}$ & $-3.16 * *$ & $1.18 * * *$ & & & \\
\hline WINFt $_{t}$ & -1.58 & $2.38 * * *$ & & & \\
\hline $\log \left(C O M_{t}\right)$ & -1.52 & $1.17 * * *$ & $\Delta \log \left(C O M_{t}\right)$ & $-4.97 * * *$ & 0.13 \\
\hline $\log \left(T O T_{t}\right)$ & -0.83 & $2.65 * * *$ & $\Delta \log \left(T O T_{t}\right)$ & $-5.44 * * *$ & 0.08 \\
\hline $\log \left(A G D P_{-i t}\right)$ & -0.60 & $3.28 * * *$ & $\Delta \log \left(A G D P_{-i t}\right)$ & $-5.21 * * *$ & 0.16 \\
\hline $\log \left(G V A_{i t}\right)$ & -0.57 & $3.27 * * *$ & $\Delta \log \left(G V A_{-i t}\right)$ & $-8.28 * * *$ & 0.10 \\
\hline $\log \left(I N V_{-i t}\right)$ & -1.25 & $2.28 * * *$ & $\Delta \log (I N V-i t)$ & $-5.22 * * *$ & 0.05 \\
\hline $\log \left(I N V_{i t}\right)$ & -1.45 & $2.63 * * *$ & $\Delta \log \left(I N V_{\text {it }}\right)$ & $-4.08 * * *$ & 0.17 \\
\hline $\log \left(E M P_{-i t}\right)$ & 0.07 & $3.28 * * *$ & $\Delta \log \left(E M P_{-i t}\right)$ & $-4.05 * * *$ & 0.06 \\
\hline $\log \left(E M P_{i t}\right)$ & 0.79 & $3.24 * * *$ & $\Delta \log \left(E M P_{i t}\right)$ & $-8.13 * * *$ & 0.13 \\
\hline$I N F_{t}$ & $-2.86 *$ & $1.16 * * *$ & & & \\
\hline$I N T_{t}$ & -1.60 & $2.03 * * *$ & & & \\
\hline $\log \left(T W I_{t}\right)$ & -1.49 & $2.21 * * *$ & $\Delta \log \left(T W I_{t}\right)$ & $-6.39 * * *$ & 0.07 \\
\hline$U N C E R_{t}$ & $-3.73 * * *$ & 0.10 & & & \\
\hline
\end{tabular}

Only the intercept is included in the equation, 3 lags are chosen. $* * *, * *, *$ denotes rejection of the null hypothesis at the 1,5 and 10 per cent level. $\Delta$ denotes the first difference. ${ }^{35}$

${ }^{35}$ The largest industries as of 2018:4 are reported. Those being Financial and Insurance Services for output, Mining for investment and Health Care and Social Assistance for employment. All other industries display similar stationarity properties. 


\section{APPENDIX D: RESULTS}

\section{Section 4.2 results: Mining and Manufacturing sub-industries}

\section{Figure A.1}

Impulse response functions of the mining sub-industries, to a one standard deviation shock to economic uncertainty
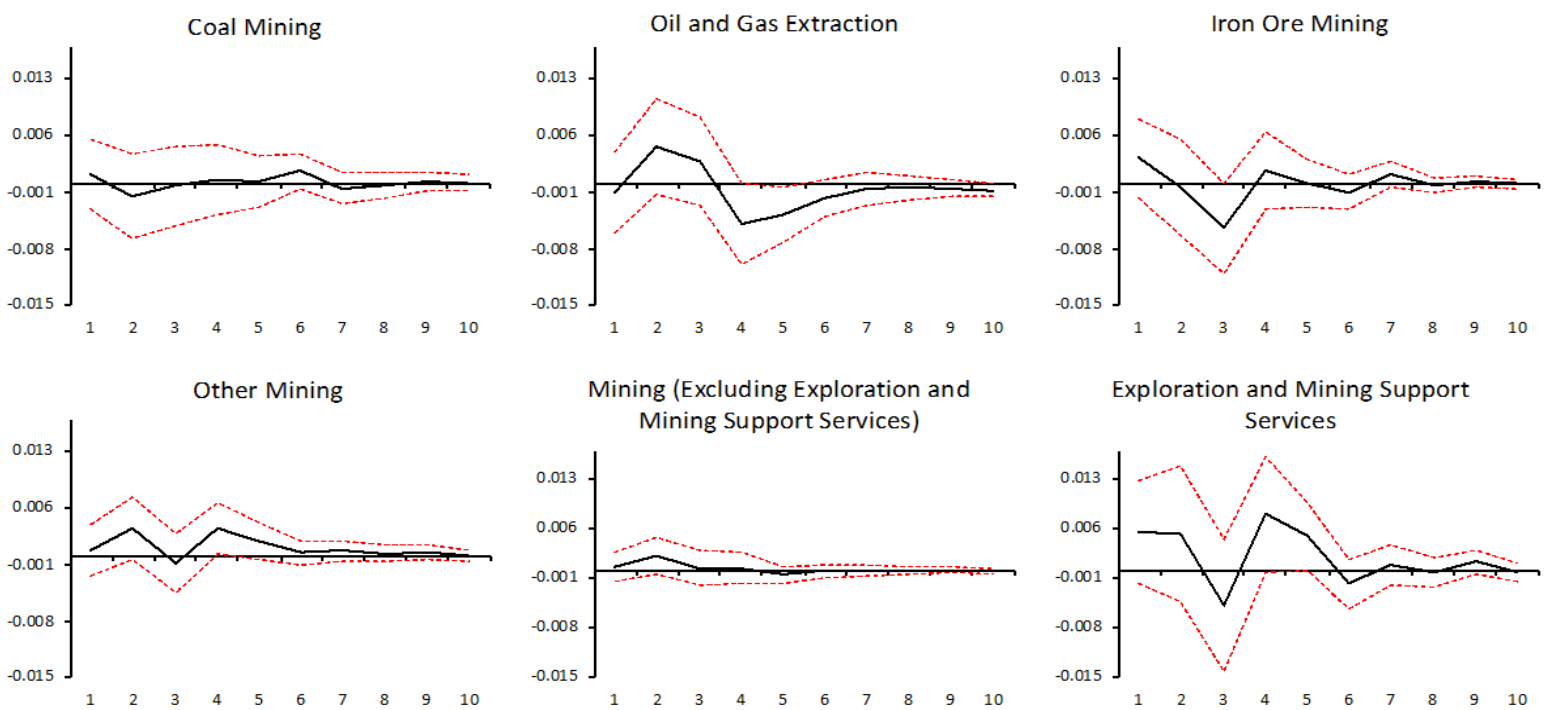

The solid black line represents the impulse response, and the dashed red lines represent the asymptotic standard error, in this study, one standard error is used. The vertical axis shows the percentage change, whereas, the horizontal axis shows periods (quarters).

Figure A.2

Impulse response functions of the manufacturing sub-industries, to a one standard deviation shock to economic uncertainty
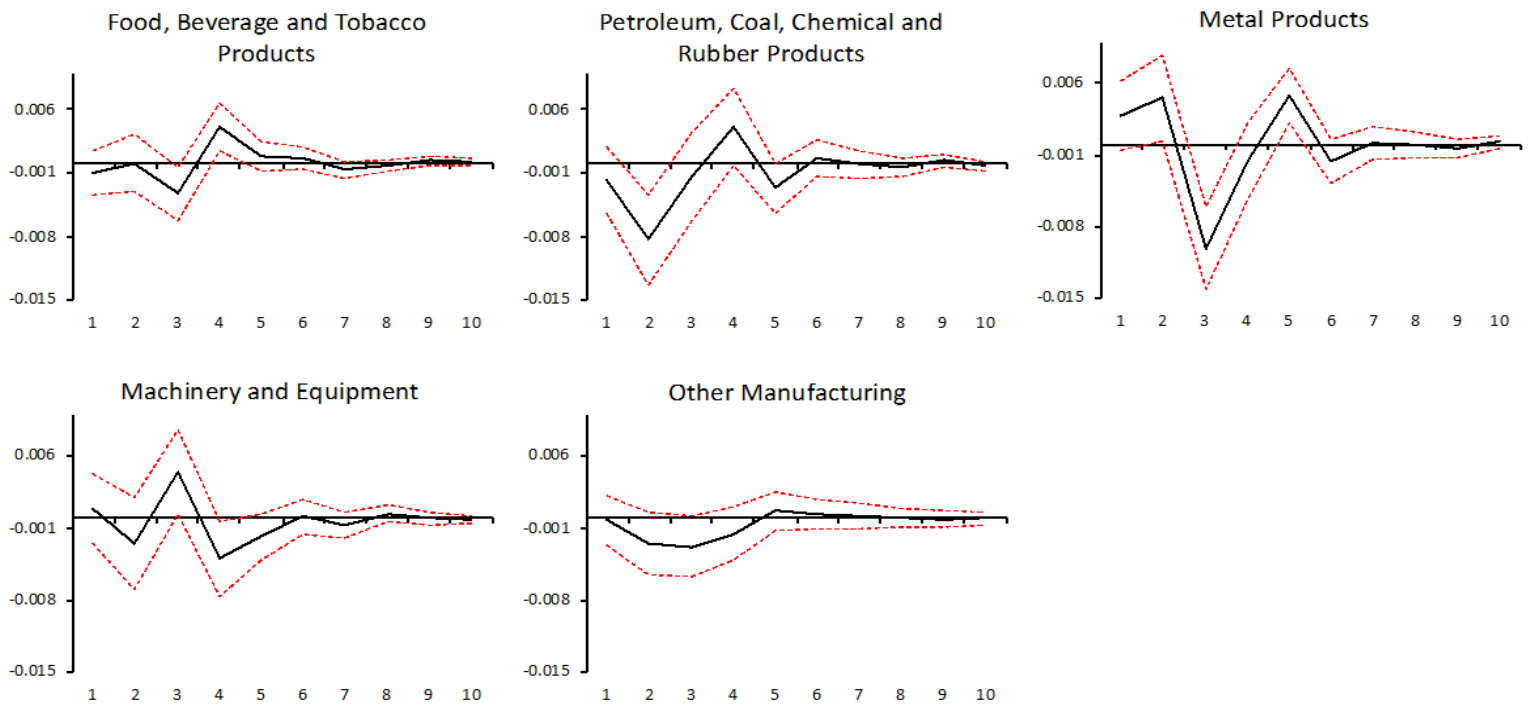

The solid black line represents the impulse response, and the dashed red lines represent the asymptotic standard error, in this study, one standard error is used. The vertical axis shows the percentage change, whereas, the horizontal axis shows periods (quarters). 


\section{Section 4.4: Australian Macroeconomic Variables}

Figure A.3

Output model, impulse response functions of aggregate Australian macroeconomic variables, to a one standard deviation shock to economic uncertainty
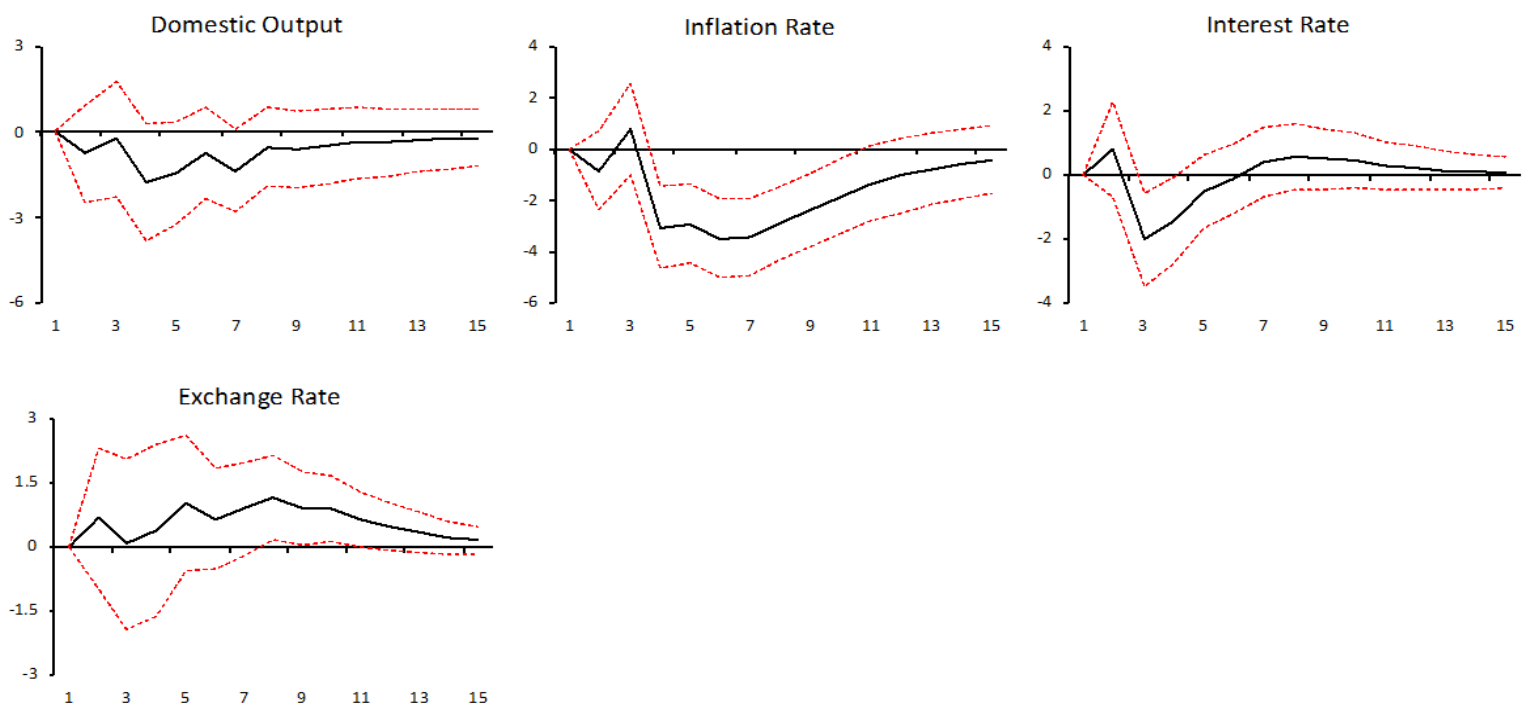

The solid black line represents the impulse response, and the dashed red lines represent the asymptotic standard error, in this study, one standard error is used. The vertical axis shows the percentage change, whereas, the horizontal axis shows periods (quarters).

Figure A.4

Investment model, impulse response functions of aggregate Australian macroeconomic variables, to a one standard deviation shock to economic uncertainty
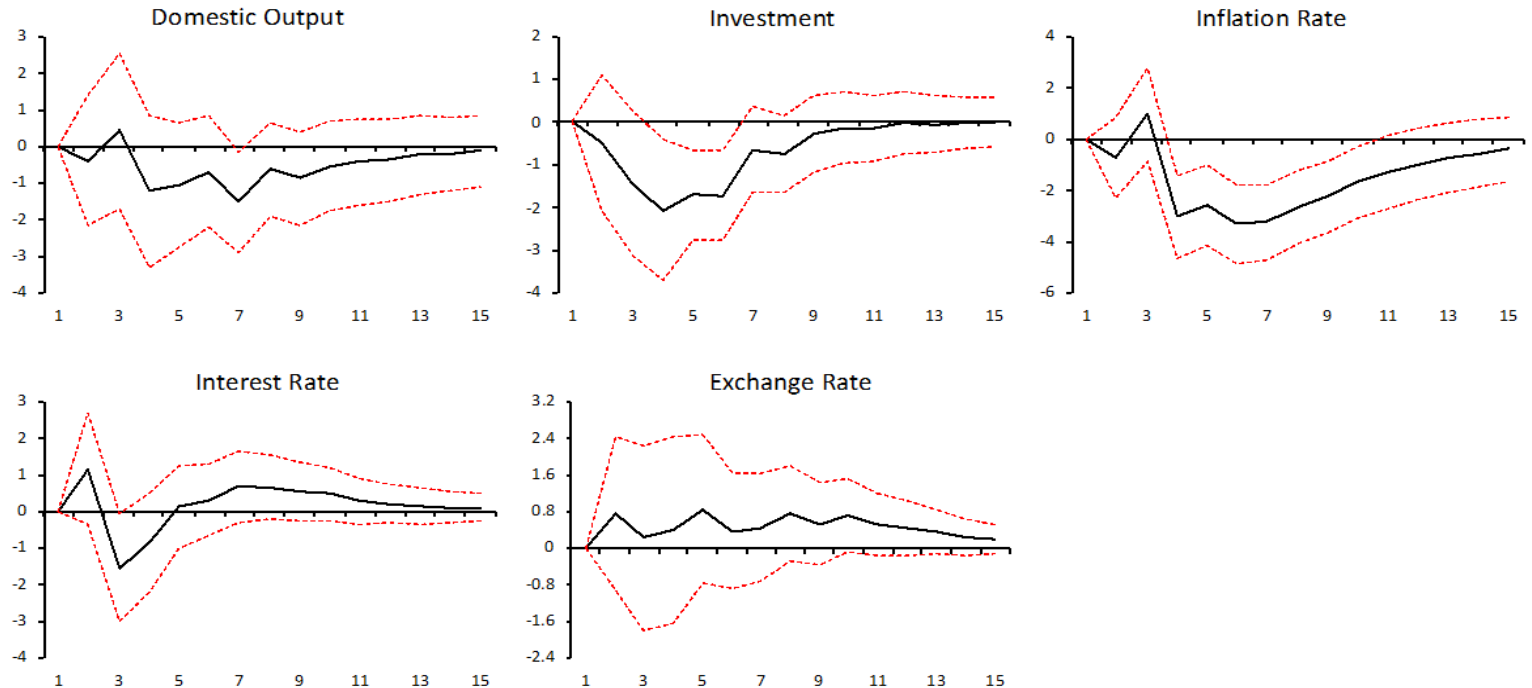

The solid black line represents the impulse response, and the dashed red lines represent the asymptotic standard error, in this study, one standard error is used. The vertical axis shows the percentage change, whereas, the horizontal axis shows periods (quarters). 
Figure A.5

Employment model, impulse response functions of aggregate Australian macroeconomic variables, to a one standard deviation shock to economic uncertainty
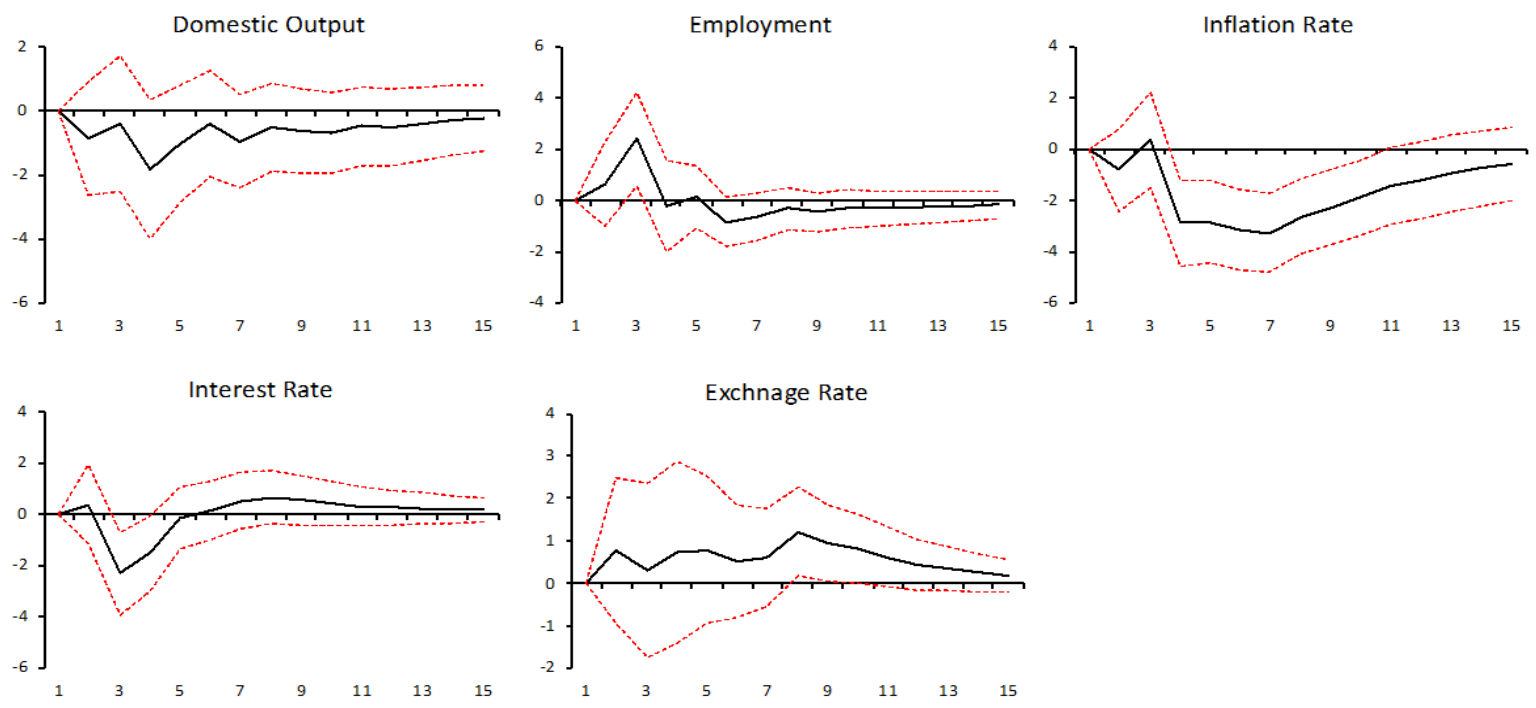

The solid black line represents the impulse response, and the dashed red lines represent the asymptotic standard error, in this study, one standard error is used. The vertical axis shows the percentage change, whereas, the horizontal axis shows periods (quarters). 


\section{APPENDIX E: ROBUSTNESS ANALYSIS RESULTS}

Figure A.6

Robustness analysis of the investment model to an economic uncertainty shock *
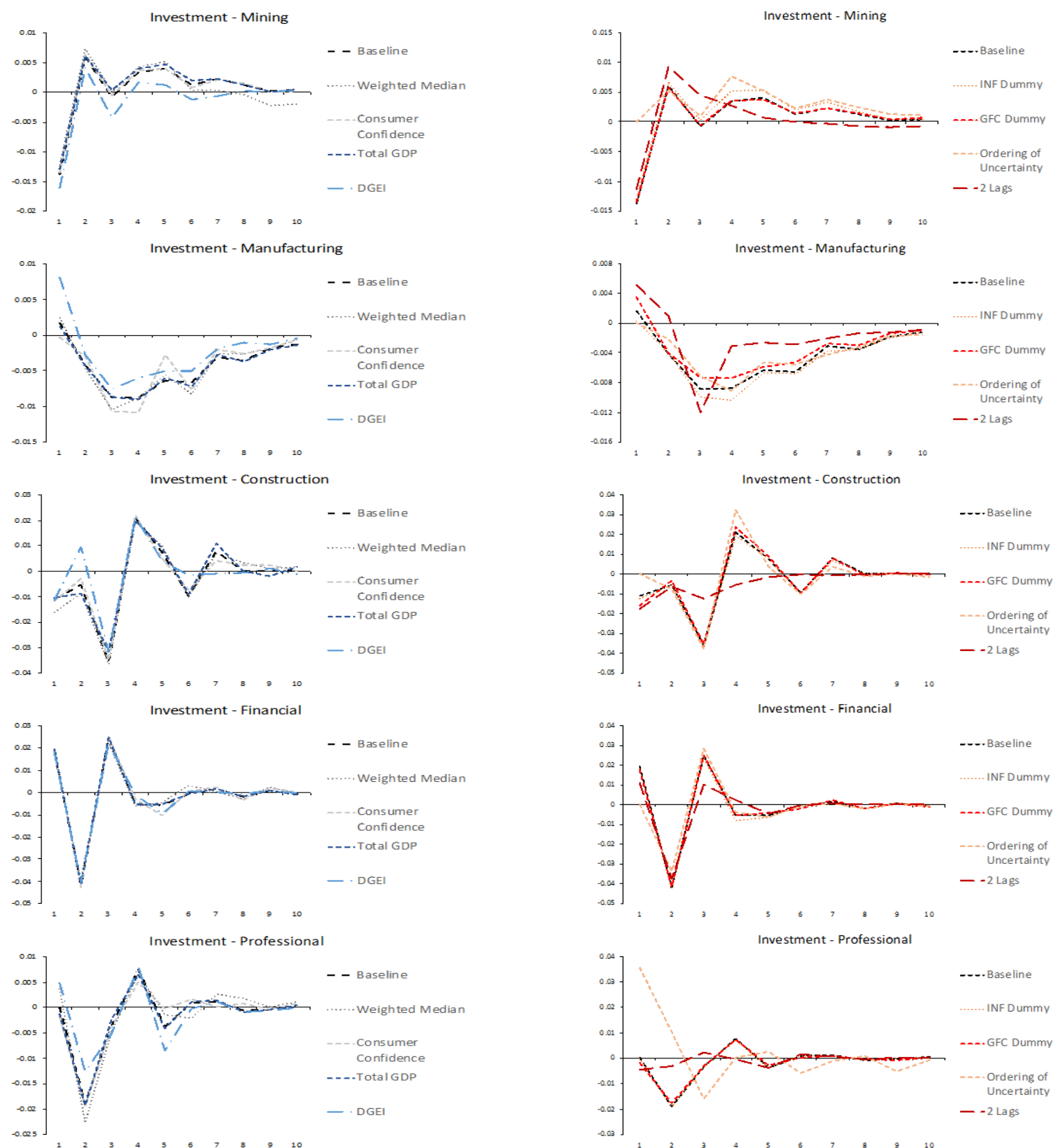

* Note that all alternative variables/proxies and identification schemes could not be evaluated since their inclusion resulted in the Hessian matrix being near singular at final iteration of the parameter values. The variables which are impacted are excluded from Figures A.6 to A.8, in this Appendix, for example, Public Administration and Safety employment exclude consumer confidence and the DGEI. 
Figure A.7

Robustness analysis of the output model to an economic uncertainty shock
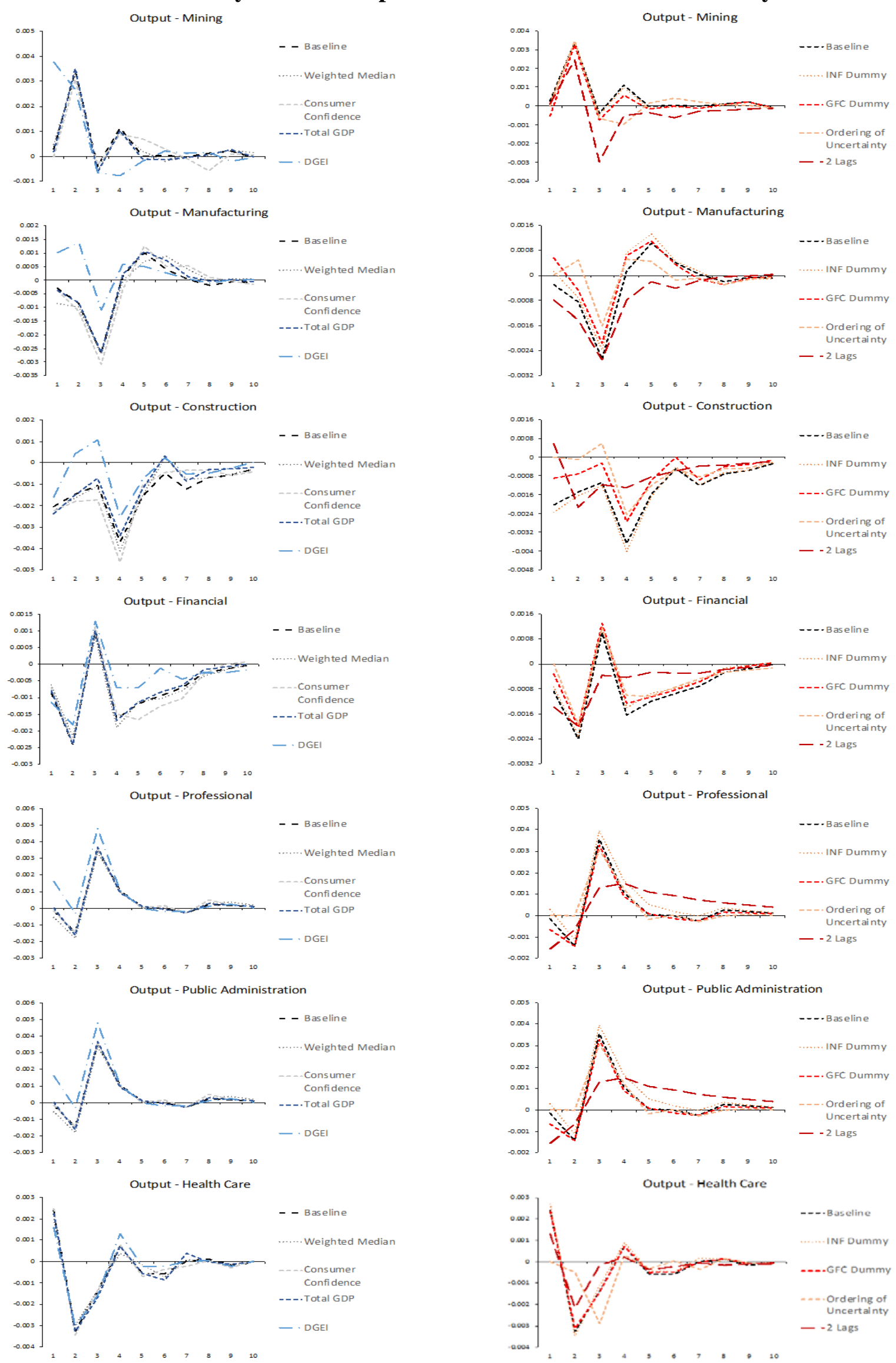
Figure A.8

Robustness analysis of the employment model to an economic uncertainty shock
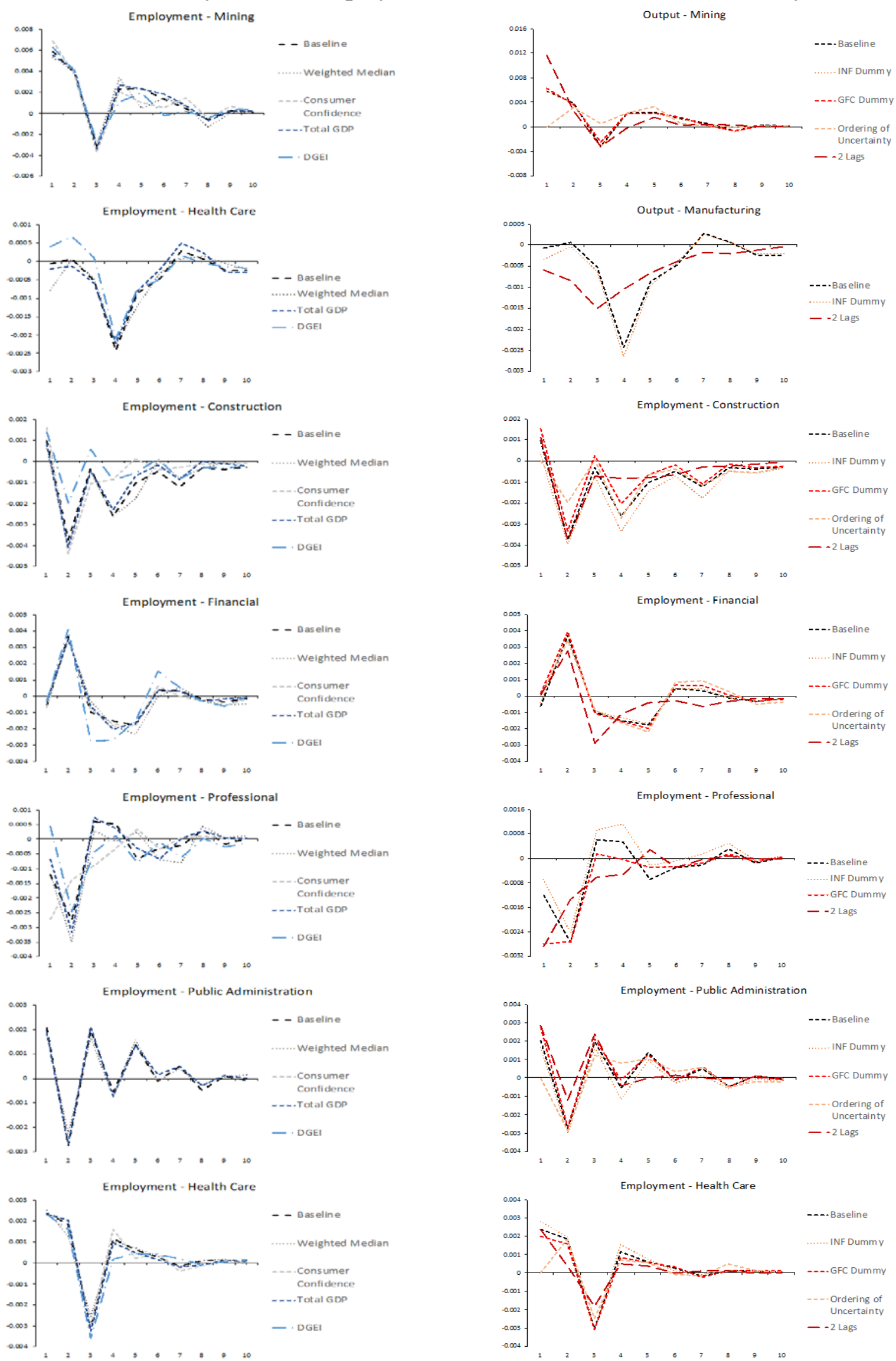